\title{
Recent Progress Trend on Abrasive Waterjet Cutting of Metallic Materials: A Review
}

\author{
Jennifer Milaor Llanto *(1), Majid Tolouei-Rad, Ana Vafadar (1) and Muhammad Aamir (1)
}

Citation: Llanto, J.M.; Tolouei-Rad M.; Vafadar, A.; Aamir, M. Recent Progress Trend on Abrasive Waterjet Cutting of Metallic Materials: A Review. Appl. Sci. 2021, 11, 3344. https://doi.org/10.3390/app11083344

Academic Editor: Andrea Spagnoli

Received: 19 March 2021

Accepted: 5 April 2021

Published: 8 April 2021

Publisher's Note: MDPI stays neutral with regard to jurisdictional claims in published maps and institutional affiliations.

Copyright: (c) 2021 by the authors. Licensee MDPI, Basel, Switzerland. This article is an open access article distributed under the terms and conditions of the Creative Commons Attribution (CC BY) license (https:// creativecommons.org/licenses/by/ $4.0 /)$.
School of Engineering, Edith Cowan University, Joondalup, WA 6027, Australia; m.rad@ecu.edu.au (M.T.-R.); a.vafadarshamasbi@ecu.edu.au (A.V.); m.aamir@ecu.edu.au (M.A.)

* Correspondence: j.llanto@ecu.edu.au

\begin{abstract}
Abrasive water jet machining has been extensively used for cutting various materials. In particular, it has been applied for difficult-to-cut materials, mostly metals, which are used in various manufacturing processes in the fabrication industry. Due to its vast applications, in-depth comprehension of the systems behind its cutting process is required to determine its effective usage. This paper presents a review of the progress in the recent trends regarding abrasive waterjet cutting application to extend the understanding of the significance of cutting process parameters. This review aims to append a substantial understanding of the recent improvement of abrasive waterjet machine process applications, and its future research and development regarding precise cutting operations in metal fabrication sectors. To date, abrasive waterjet fundamental mechanisms, process parameter improvements and optimization reports have all been highlighted. This review can be a relevant reference for future researchers in investigating the precise machining of metallic materials or characteristic developments in the identification of the significant process parameters for achieving better results in abrasive waterjet cutting operations.
\end{abstract}

Keywords: abrasive waterjet; machining; metal cutting; process parameters; optimization

\section{Introduction}

Cutting is the process of applying a force to penetrate or separate a workpiece [1]. With current advances in technologies, there has been a rapidly increasing demand for quality cut parts with complex geometries in the fabrication industry. Abrasive waterjet machining (AWJM) is an advanced technology that can be used for cutting processes. AWJM was developed from plain waterjet machines, wherein in 1980 abrasives were first added to plain waterjets to cut industrial material [2]. AWJM allows for versatility in machining an extensive range of materials, from the easiest to the most strenuous to cut. AWJM is recognized as an implicit solution for machining metallic and heat-sensitive materials without leaving a heat-affected zone (HAZ) or any residual stresses during the machining process [3]. Among the various advanced machining technologies, AWJM has exhibited significant emergence in manufacturing industries due to its extensive operations and exceptional quality of cut of intricate profiles with a minimum cutting force on the workpiece and yield of better dimensional accuracy due to insignificant distortion [4]. However, AWJM with proper process parameter settings remains a challenging procedure for manufacturers. Therefore, an enhanced understanding of AWJM mechanisms and modelling is needed to ensure more effective applications.

This review aims to address gaps in existing studies by foregrounding the leading features of the abrasive waterjet (AWJ) cutting of metallic materials and providing significant, up-to-date research from the theoretical and experimental analysis. This paper is structured to present AWJM mechanism advantages and applications, and identifies limitations and current challenges faced by AWJ cutting, as well its process parameter functions and influences. Accordingly, recent process parameter improvements and optimizations are reviewed. 


\subsection{Abrasive Waterjet Machining System}

In the AWJM system, materials are removed using erosion processes. Erosion is a type of wear with the manifestation of accelerating and the continuous collision of abrasive particles in a high velocity in liquid form [4]. An example of a typical AWJM is shown in Figure 1 [5]. The underlying operating structure of AWJM includes a high-pressure pump system, a cutting head, a table and a computer-based controller [6].

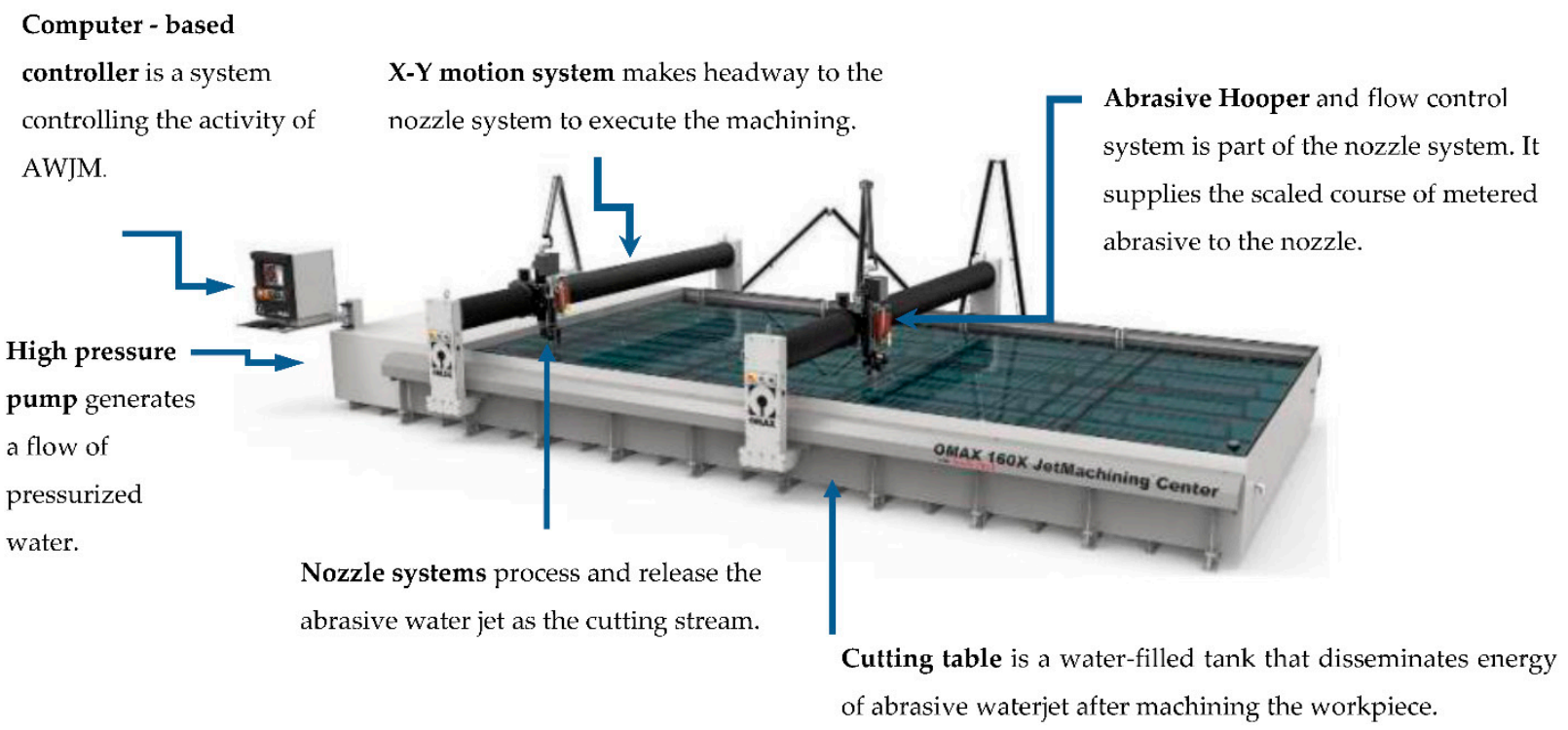

Figure 1. AWJM mechanism and components [5].

The computer-based controller is incorporated into the AWJM system, functioning independently, which enables to download varied types of diagram programs. This comprises tools that are distinct to AWJM, such as manual or automatic cut in/out tools, tools for the generation of cutting paths, collision prediction and resolution, tool assignment for surface quality, etc. [7]. Mixing the granular abrasive with a high-pressure waterjet stream makes the AWJM capable of machining. A high-pressure pump drives the pressurized water in the nozzle system. This system includes an abrasive hopper, orifice, mixing chamber and focusing tube. The water travels with a high level of velocity and is forced out of the orifice in a very thin stream structure [8]. A hopper that includes a plastic tube holds abrasive particles and dispenses them to the cutting head, where particles are then drawn into a waterjet stream in the mixing chamber. The high-speed waterjet, set alongside abrasive particles, is compounded and accelerated to create an abrasive waterjet. The focusing tube directs the abrasive waterjet to its focal point when cutting a working piece [9].

\subsection{Abrasive Waterjet Erosion Mechanism}

The AWJM process of removing material from a target workpiece emerges through an erosive venture of abrasive particles travelling with high velocity [10]. Material removal rates in AWJM transpire across two primary models, such as cutting and deformation/ploughing deformation wear mechanism [4]. Erosion mechanisms vary depending on workpiece material and properties [11]. A workpiece can be categorized as ductile, brittle or composite. In ductile materials, erosion can occur using two procedures, i.e., repeated plastic deformation and cutting action. In general, ductile erosion is applicable to metals and other similar materials that are capable of a significant plastic deformation process [12]. For the brittle materials erosion process, removal of material occurs through crack propagation and chipping, resulting in contact stresses caused during the impact of abrasive particles, which is then defined as the cracking method [13]. In the case of 
composite materials, abrasives penetrate the material and produce breakages that initiate the formation of cracks, which in turn results in delamination [14].

\subsection{AWJM Process and Advantages}

The cutting process is a core method in the manufacturing industry. AWJM is highly capable of machining from hard to soft materials at a very low machining force, which avoids the destruction of the target workpiece's properties [3]. Abrasive waterjet machining is a non-conventional cold processing technology used for material processing with significant advantages [1,15], which has been the reasoning behind the rapidly progressing application of AWJM, particularly in metallic materials [6]. The reduction of temperature is carried through the presence of cooling water due to the presence of cooling water, which renders AWJM [6].

Table 1 illustrates AWJM's superiority compared to other non-conventional machines based on experimental studies on various workpieces [8-10,16-21]. It substantiates AWJM compared to other technologies, indicating versatility in cutting diverse material with a wide range of thickness, absence of tool wear and flexibility in cutting intricate geometries. Other machines such as EDM and ECDM involve the use of high-intensity energy to cut hard metals and materials that are difficult to machine [8-10]. However, the usage of high thermal heating sources causes craters, cracks, thermal damages, and destructively tensile residual stresses; hence, materials that are low conductors of heat are very applicable [10]. In AWJM applications, the absence of thermal distortion is achieved due to its cold cutting process since the material temperature will not exceed $70{ }^{\circ} \mathrm{C}$ [22]. EDM and ECDM generate hazardous solid, liquid, and gaseous products resulting in sludge containing metal ions, acids, nitrate, oils and even traces of heavy metal ions due to anodic electrochemical dissolution, which are very harmful to humans and the environment [17]. AWJM is also considered environmentally friendly and sustainable as it does not omit any hazardous vapor; hence, AWJM generates waste such as abrasives that adversely affect the environment. Sustainable manufacturing aims to achieve an efficient operation at the same time, reducing the environmental effect [17]. Recycling and reusing these abrasives make AWJM more economical, effective, and environmentally friendly [22-24]. The discussed competitive advantages of AWJM have been the rational reason behind its expanding utilization and continuous progression.

Table 1. Comparison of non-conventional cutting technologies [8-10,16-21].

\begin{tabular}{|c|c|c|c|c|}
\hline Cutting Activity & AWJM & LBM & EDM & ECDM \\
\hline $\begin{array}{l}\text { Heated affected } \\
\text { zone (HAZ) }\end{array}$ & No & Yes & Yes & Yes \\
\hline Material Distortion & No & Yes & No & Yes \\
\hline Tool Wear & No & No & Yes & Yes \\
\hline $\begin{array}{l}\text { Material Removal } \\
\text { Rate }\left(\mathrm{mm}^{3} / \mathrm{s}\right)\end{array}$ & $\begin{array}{l}\text { Medium-slow } \\
(\text { approx. } \leq 2)\end{array}$ & $\begin{array}{c}\text { Fast (approx. 2-3) for } \\
\text { non-reflective } \\
\text { materials only }\end{array}$ & Medium (approx.1-2) & Medium (approx.1-2) \\
\hline Type of material & $\begin{array}{c}\text { metals, composites, } \\
\text { natural, electrically, } \\
\text { non-conductive, } \\
\text { non-reflective }\end{array}$ & $\begin{array}{c}\text { metals, composites, } \\
\text { natural, electrically, } \\
\text { non-conductive, } \\
\text { non-reflective surface }\end{array}$ & $\begin{array}{c}\text { Only electrically } \\
\text { conductive such as } \\
\text { metals and composites }\end{array}$ & $\begin{array}{c}\text { Only electrically } \\
\text { conductive such as } \\
\text { metals and composites }\end{array}$ \\
\hline $\begin{array}{l}\text { Material thickness } \\
(\mathrm{mm})\end{array}$ & Ranging $\leq 304.8$ & Ranging $\leq 20$ & Ranging $\leq 304.8$ & Ranging $\leq 304.8$ \\
\hline Type of shapes & $\begin{array}{c}\text { Complex and } \\
\text { complicated shapes }\end{array}$ & $\begin{array}{c}\text { Complex and } \\
\text { complicated shapes }\end{array}$ & Simple & Simple \\
\hline Burr formation & Minimal & High & High & Minimal \\
\hline Hazardous vapour & None & fumes, gases & $\mathrm{CO} \& \mathrm{CH}_{4}$ & $\mathrm{NaOH} / \mathrm{NaNO}_{3}$ \\
\hline
\end{tabular}




\subsection{Abrasive Waterjet Machining Application}

In the past and recent years, AWJM has gained high interest amongst researchers, as it is a versatile tool that is used in almost all manufacturing processes and materials. Figure 2 presents the statistics of various workpieces utilized in AWJM applications, as established from several reviewed publications [25-66]. The first chart (a) shows a generated summary of various workpieces that have been employed in AWJM applications, while the second chart (b) represents created synopsis material types for enhanced analysis based on several research studies used from the year 2017 to 2020.

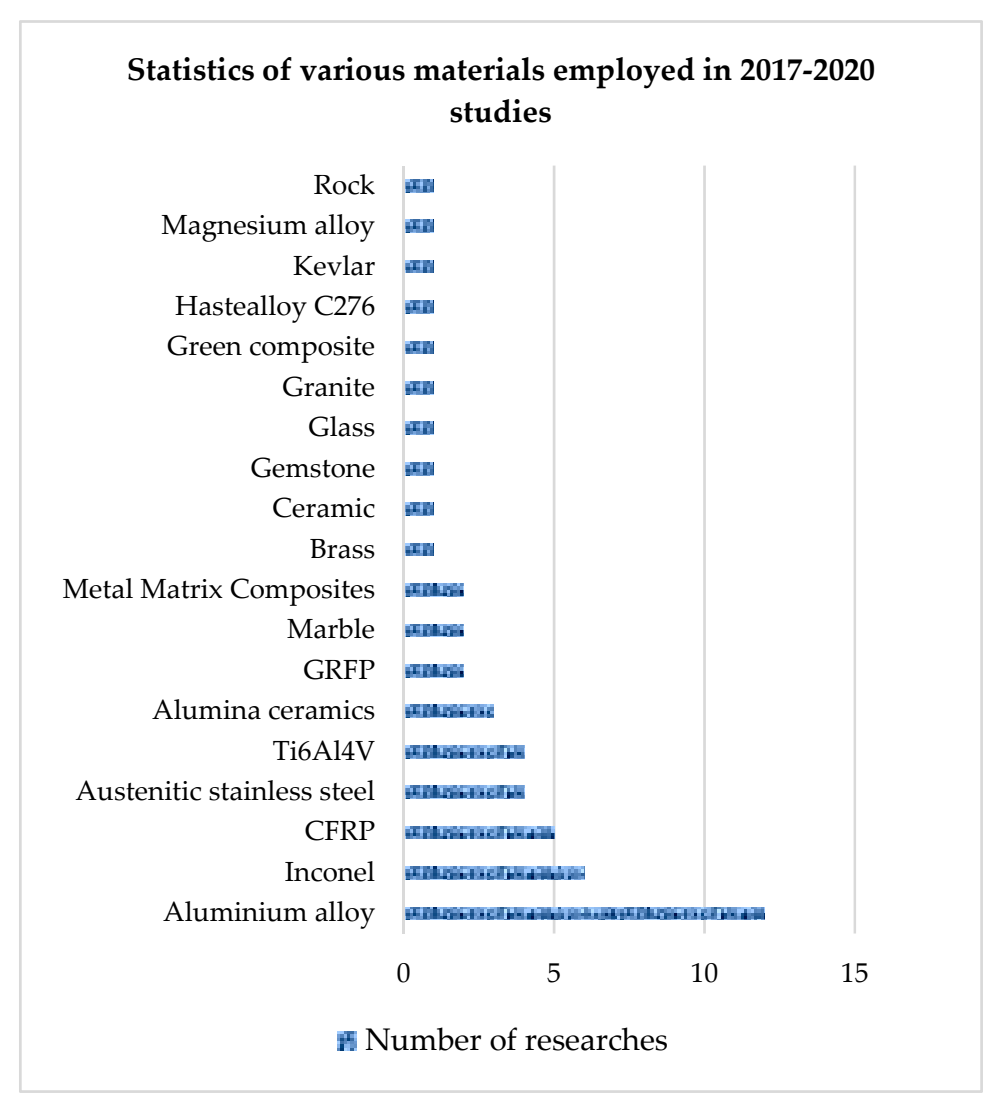

(a)

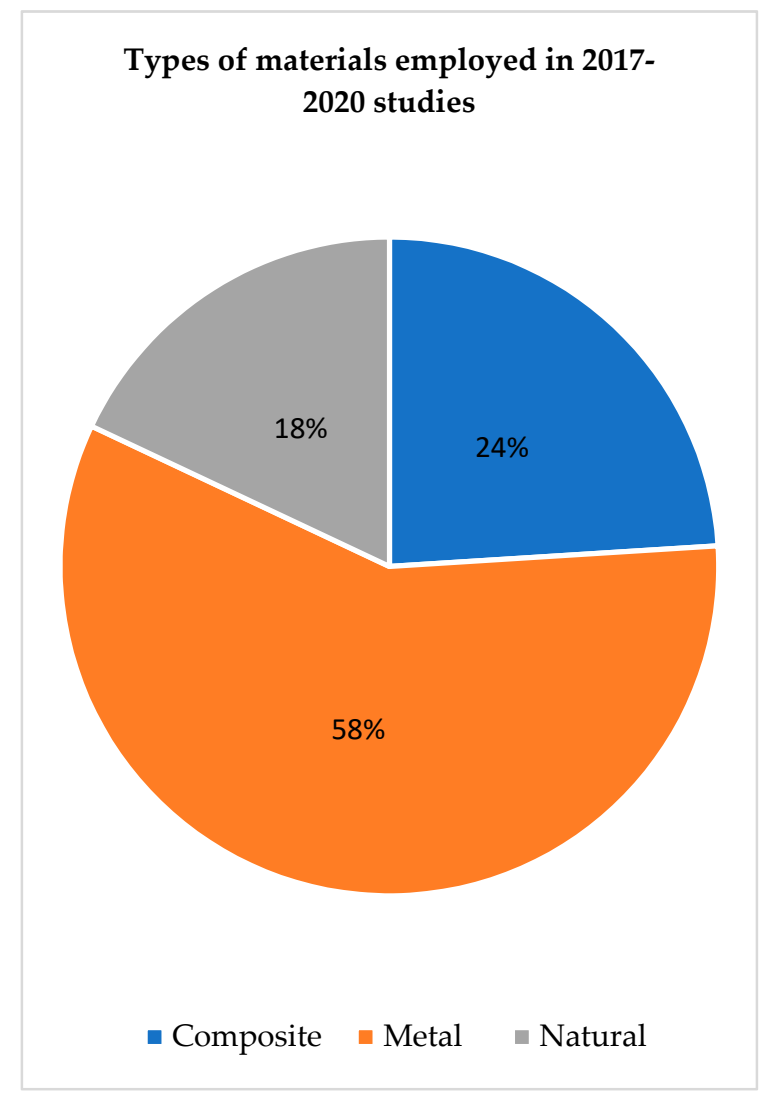

(b)

Figure 2. Statistics of (a) various workpieces employed in AWJM applications and (b) material type from 2017 to 2020 publications reviewed in this work.

A number of studies in metal, composite, and natural materials discovered similar quality defects such as surface roughness, striation marks and kerf geometry inaccuracies [25-66]. As shown in Figure 2a, aluminum alloy, which is a metallic material, has captured the highest value of twelve (12) research studies, whilst natural material, rock, has gained the least attention amongst these selected recent researches in AWJM application. As illustrated in Figure $2 b$, metal materials have received the highest attention, attaining $58 \%$ of the population of these selected latest studies in AWJM performance. These are difficult-to-cut materials that possess drawbacks related to their high alloying content (i.e., chromium and nickel), low thermal conductivity, high ductility, and low machinability level [67]. It was noted that the mentioned quality issues and defects are highly influenced by their material properties [68,69].

Varied types of materials possess divergent machinability due to their different mechanical and chemical properties, and a number of metallic materials identified as one of the most hard-to-cut materials [28]. Figure 3 illustrates the typical machinability of several 
employed materials in abrasive waterjet (AWJ) cutting applications [69]. The machinability index indicates the speed of the machining process.

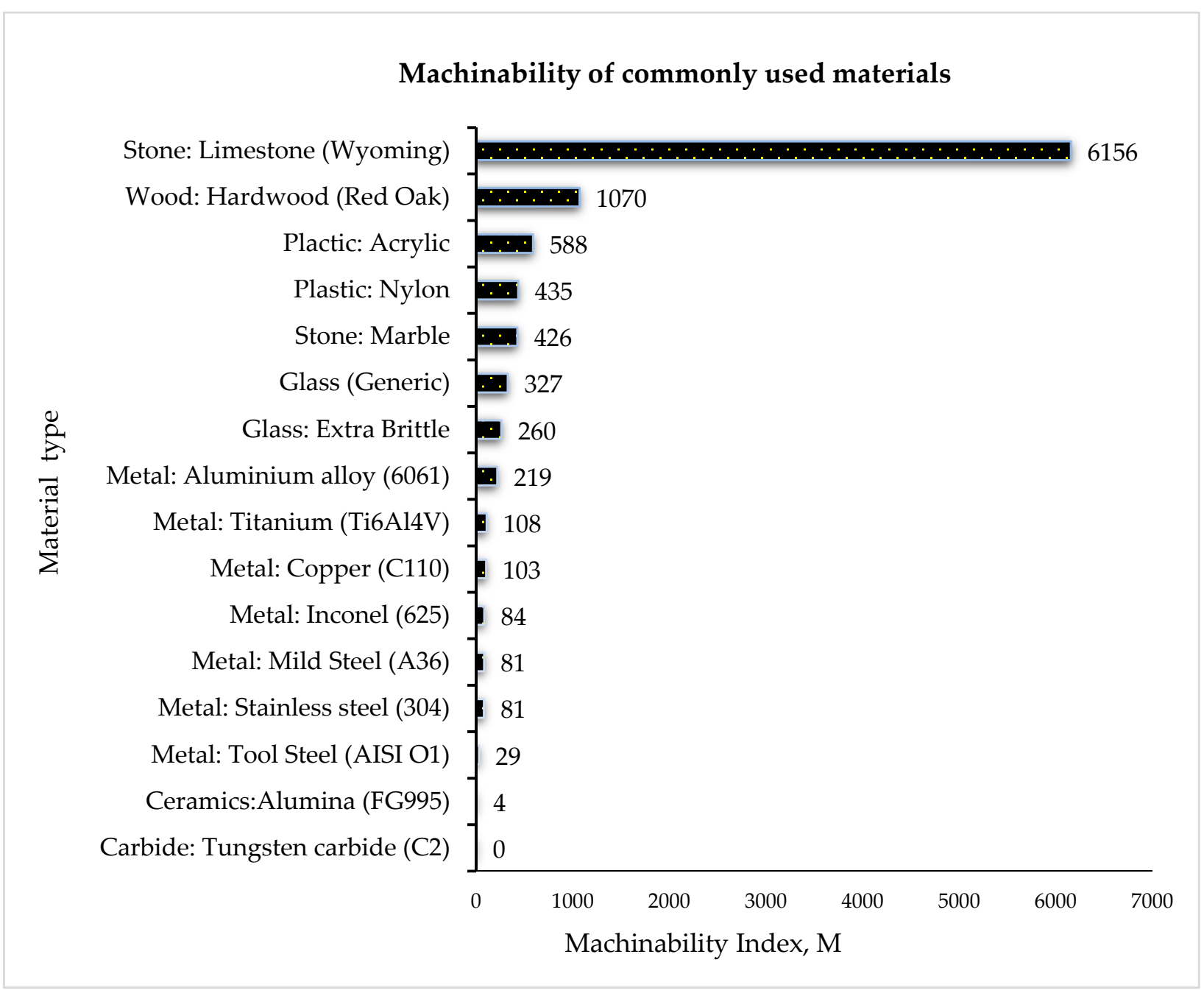

Figure 3. Machinability of frequently employed materials in AWJ cutting applications [69].

Cutting machinability can be estimated by several indices such as the forces merging while cutting, cutting speed, surface quality of cut material, etc. [69]. Moreover, a higher machinability index denotes a faster cutting speed which has been established based on extensive cutting tests [69]. Figure 3 also demonstrates that tungsten carbide denotes the lowest level of machinability, subsequently followed by ceramics and metals such as stainless steel, Inconel and titanium; in this regard, these workpieces are the most difficult-to-machine materials.

AWJM has also been recognized to be an effective technology in cutting non-conducting material with a low machinability index. Research to date has explored differing operating mechanisms of AWJM for various industrial conditions and applications. Table 2 enumerates AWJM applications in different industry sectors with regards to specific material usage [49,70-72], which shows that AWJM applications cover a vast range of industrial domains. 
Table 2. AWJM materials and areas of application [49,70-72].

\begin{tabular}{cll}
\hline \multicolumn{1}{c}{ Materials } & \multicolumn{1}{c}{ Workpiece } & \multicolumn{1}{c}{ Industrial Application } \\
\cline { 1 - 3 } Type & \multicolumn{1}{c}{$\begin{array}{c}\text { Concrete, cement, ceramics, graphite, stone } \\
\text { or rock. }\end{array}$} & $\begin{array}{l}\text { Mining, manufacturing and processing of ceramics and } \\
\text { graphite, building, construction, housing, and tile industry. }\end{array}$ \\
\hline Metals & Titanium, aluminium, stainless steel, and alloys. & $\begin{array}{l}\text { Automotive, marine, aerospace, architecture and civil, } \\
\text { medical, food industry, automotive, electronics industry. }\end{array}$ \\
\hline Composites & $\begin{array}{l}\text { Wire glass, laminated glass, optic glass, } \\
\text { composites, and magnetic materials. }\end{array}$ & $\begin{array}{l}\text { Aerospace, automotive, electronics industry, Glass, } \\
\text { decorations, promotional, optical fiber, and the } \\
\text { medical industry. }\end{array}$ \\
\hline
\end{tabular}

After expounding the machining mechanism and benchmarking performance against other non-conventional technologies, in addition to enumerating the advantages and applications of AWJM, it is essential to discern the technology's current conditions, limitations and process drawbacks that affect its technological effectiveness. A very high noise (approximately 80 to $100 \mathrm{Db}$ ) is produced by AWJM during the machining process, and acquisition costs are driven by the high-pressure pump, high volume of required water quality, and purity $[3,6,15,24]$. Therefore, recent states of AWJM applications, boundaries, and challenges, particularly in cutting operations, are further discussed in the succeeding sections of this review.

\section{Abrasive Waterjet Cutting Application Limitations and Challenges}

AWJM is extensively used for cutting operations; hence, there is a necessity for enhancing its performance. AWJ cutting processes still face challenges in quality and productivity performance, mostly metallic material identified as one of the hard-to-cut material due to its low machinability. There have been reported cutting defects when using an abrasive waterjet machine. Damage may also vary depending on the material to be machined [73]. The issue of material response to AWJM in terms of its behavior, i.e., burr formation, high surface roughness, striation marks, distorted kerf geometry, and delamination, has been studied since the beginning of AWJM applications in the 1980s $[74,75]$. Table 3 shows common AWJ cutting issues that have been restudied by researchers, particularly metallic materials.

Table 3 details that previous works have encountered similar customary defects inherent in this machine's application for difficult-to-cut materials, particularly metals $[15,62,76-78]$. Several studies have shown that AWJ cutting has been broadly applied to metallic materials with varied thicknesses. The AWJ cutting process has also been revealed to contain similar defects, such as kerf taper, roughness and cracking of cutting metals regardless of the thickness. A summary of recent studies applying AWJ cutting of metals with varied thicknesses is itemized in Table 4.

As shown in Table 4, the kerf taper angle and surface roughness are major quality issues identified in the AWJ cutting of metallic materials with varied thickness. Accordingly, a machinability study performed by Khan et al. [79] detailed the AWJM performance in cutting low alloy steel of different thicknesses $(5,10,15,20 \mathrm{~mm})$. Their experiments revealed that the material thickness impacts machine performance, such as the material removal rate, surface roughness, and kerf wall inclination. Hence, it is necessary to investigate the influence of material thickness for precise AWJM, as cutting operations involve various thicknesses of product formation in fabrication industries.

The aforementioned issues are challenges to AWJ cutting performance. However, these issues have been recently reinvestigated and it was concluded that AWJM performance relies on its process parameters. Therefore, it is necessary to have a continuous comprehensive study of process parameters to improve AWJ cutting performance, which is discussed in the succeeding section. 
Table 3. AWJ cutting defects amongst various metallic materials [15,62,76-78].

\begin{tabular}{|c|c|c|c|}
\hline Defects & Material & Images & Key Findings and References \\
\hline $\begin{array}{l}\text { Cutting residue, } \\
\text { striation and roughness }\end{array}$ & AISI 304 & & $\begin{array}{l}\text { Miao et al. [76] have found quality } \\
\text { defects such as cutting residue, kerf } \\
\text { taper and striation in cutting AISI } 304 \\
\text { using abrasive waterjet machine. These } \\
\text { defects are caused by the decreasing } \\
\text { energy of the jet. }\end{array}$ \\
\hline Kerf taper angle & AISI 1090 & & $\begin{array}{l}\text { Mohamad et.al. [62] have identified the } \\
\text { kerf taper angle as an intrinsic } \\
\text { characteristic of AWJ cutting of AISI } \\
1090 \text { mild steel. They determined that } \\
\text { variation in the kerf top width wider } \\
\text { and kerf bottom geometries resulted in } \\
\text { a higher kerf taper angle. }\end{array}$ \\
\hline Surface Roughness & Ti-6Al-4V & & $\begin{array}{l}\text { Gnanavelbabu et al. [77] applied AWJ } \\
\text { cutting of Ti-6Al-4V and observed } \\
\text { roughness and striations marks in cut } \\
\text { surfaces. They discovered that the cut } \\
\text { surface finish differs depending in the } \\
\text { depth from surface entry of the } \\
\text { abrasive jet. }\end{array}$ \\
\hline $\begin{array}{l}\text { Material removal rate, Kerf } \\
\text { taper angle }\end{array}$ & Inconel 600 & & $\begin{array}{l}\text { Uthayakumar et al. [78] have known } \\
\text { quality defects, such as kerf geometric } \\
\text { inaccuracy and a low material removal } \\
\text { rate in cutting super nickel alloy using } \\
\text { abrasive waterjet machine. They } \\
\text { established a high occurrence of } \\
\text { inaccurate kerf geometries using a high } \\
\text { level of water pressure and increasing } \\
\text { the traverse speed. }\end{array}$ \\
\hline Depth of Cut & SS304 & & $\begin{array}{l}\text { Supriya et al. [15] have determined that } \\
\text { one of the challenges faced with cutting } \\
\text { stainless steel is achieving a high depth } \\
\text { of cut due to its low machinability. } \\
\text { They concluded that using abrasive } \\
\text { waterjet machine with a high level of } \\
\text { pressure settings have increased the } \\
\text { depth of cut. }\end{array}$ \\
\hline
\end{tabular}

Table 4. Quality defects in AWJ cutting of metallic with different thickness $[18,61,77,80]$.

\begin{tabular}{cccc}
\hline Year \& Author & Metallic Material & Thickness & Defects \\
\hline Gnanavelbabu et al. 2018 [77] & Ti6Al4V & $5 \mathrm{~mm}$ & KTA, MRR, Ra \\
Wang et al. 2019 [61] & AA 6061-T6 & $5,10,25,50 \mathrm{~mm}$ & KTA \\
Yuvaraj et al. 2017 [80] & AISI D2 Steel & $60 \mathrm{~mm}$ & Ra \\
Akkurt et al. 2018 [18] & SS 304 & $20 \mathrm{~mm}$ & Ra \\
\hline
\end{tabular}

\section{Abrasive Waterjet Cutting Process Parameters and Influences}

The abrasive waterjet (AWJ) cutting process incorporates several independent process parameters that directly affect the machine's performances. As illustrated in the causeand-effect diagram of the AWJM process parameters given in Figure 4, the input process parameters are categorized as follows (1) hydraulic, (2) nozzle, (3) material, (4) abrasive, and (5) cutting. The input process parameters primarily affect the machining performance or output parameters of AWJM application. Learning the specific functions of these influential 
variables will be fundamental towards development and improvement initiatives of quality and efficiency of the entire cutting process.

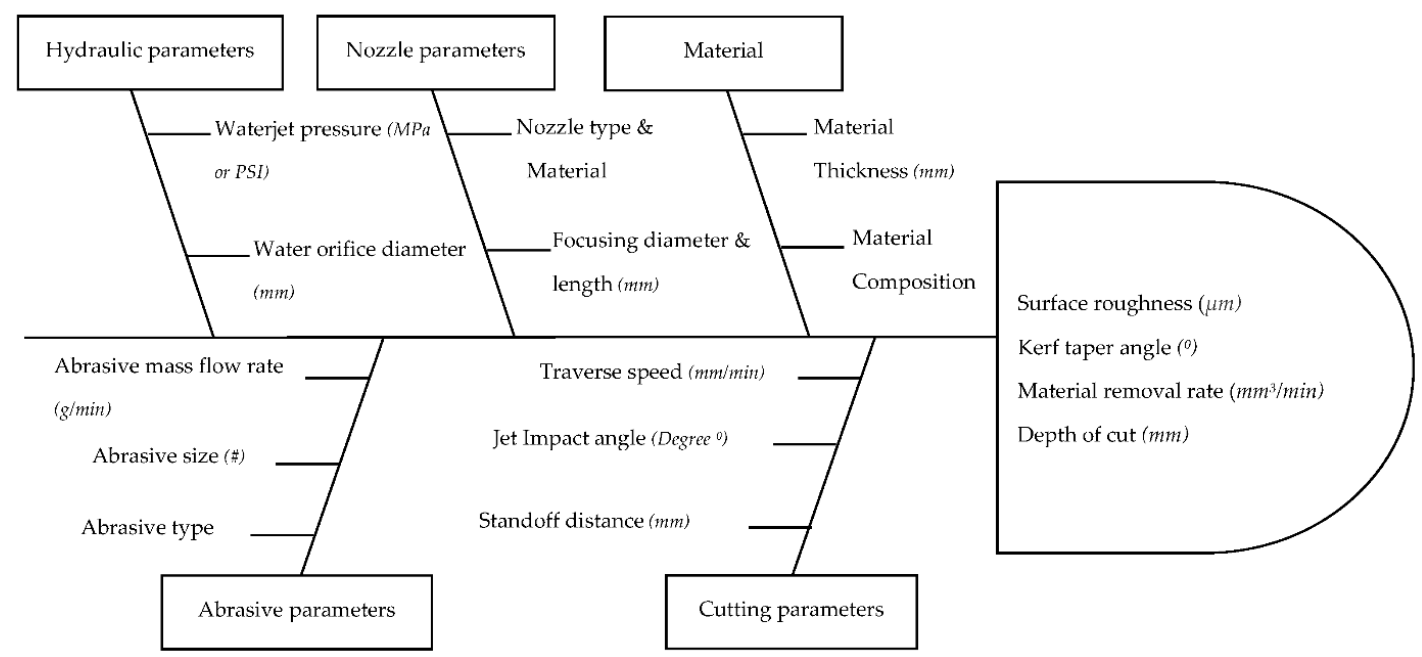

Figure 4. Cause-and-effect diagram of AWJM process parameters $[9,81]$.

\subsection{Abrasive Waterjet Cutting Input Process Parameters Functions and Influences}

The AWJ cutting input process parameters are comprised of specific functions governing the execution of various machining operations.

\subsubsection{Hydraulic System}

The hydraulic system is the waterjet pressure denoted by $(\mathrm{P})$ and measured in $\mathrm{MPa}$ or PSI. A continuous flow of pressurized water generated from the AWJM water pressure pump drives the cutting head controlled by an accumulator and pressure tubing $[3,6]$.

Impacts of waterjet pressure: Waterjet pressure affects the distribution of water and jet abrasive particles during material erosion processes. Naresh Babu, M. et al. [82] have recommended that high-level pressure, with a value of $399 \mathrm{MPa}$, can acquire superior surface quality in cutting brass-360. Additionally, Akkurt et al. [83] have utilized an ultrahigh-pressure (UHP) waterjet cutting system in evaluating deformation on materials with the same composition but different thicknesses such as Al-6061 aluminum alloy, brass353, AISI 1030, and AISI 304 steel materials. Their experiment showed that a very high waterjet pressure negatively affects the surface roughness as the thickness of the material decreases. A high-level water pressure produces high velocity, resulting in a stronger impact of abrasive particles [49]. Ultra-high-pressure (UHP) AWJM pumps provide water pressure to the cutting head at continued pressures from 40,000 psi (276 MPa) to $87,000 \mathrm{psi}$ $(600 \mathrm{MPa})$ and have progressed its industrial application since its commercialization due to its wide range of application, i.e., 2D shape cutting, surface grounding, weight reduction of space-borne mirrors, and various machining tasks tasks [84]. Pashmforoush et al. [85] have observed that geometrical tolerances were obtained by increasing waterjet pressure to a value of $300 \mathrm{MPa}$ when cutting Hardox 400 steel. The achieved results denote that by the increase of jet pressure, the surface quality improves and the geometrical errors are reduced. This is similar to Khan et al. [79] as they have concluded that a jet pressure of $240 \mathrm{MPa}$ can yield a high material removal rate for AWJ cutting of EN24 Steel 14. These previous works established that waterjet pressure is directly proportional to the depth of jet penetration and the material removal rate.

\subsubsection{Abrasive System}

The abrasive system is composed of abrasive material type, size, shape, and flow rate. The abrasive mass flow rate is the stream of its particles alongside waterjet pressure, which is typically measured in $\mathrm{g} / \mathrm{min}[6]$. 
Impacts of abrasive type: Abrasives are categorized into natural, zirconia alumina, glass, steel, and copper. These types have inherent diverse characteristics such as the level of hardness and grit shape. In particular, Perec et al. [64] have conducted an experiment in cutting titanium using different abrasives, i.e., garnet, olivine, and crushed glass abrasives. Based on his experiments, garnet gave the highest material removal or cut penetration. Later, they carried out a comparative investigation between garnet and corundum abrasive. They concluded that corundum abrasive applications could be suggested within certain economic circumstances due to the decreased lifespan of focusing tubes [86]. Furthermore, it has been established that AWJ cutting performance is vastly affected by the density, shape, and hardness of abrasives. Table 5 exhibits categories of abrasive materials utilized in various industries, in conjunction with their details and properties.

Table 5. Abrasive material categories along with their properties and industrial applications $[1,68,87,88]$.

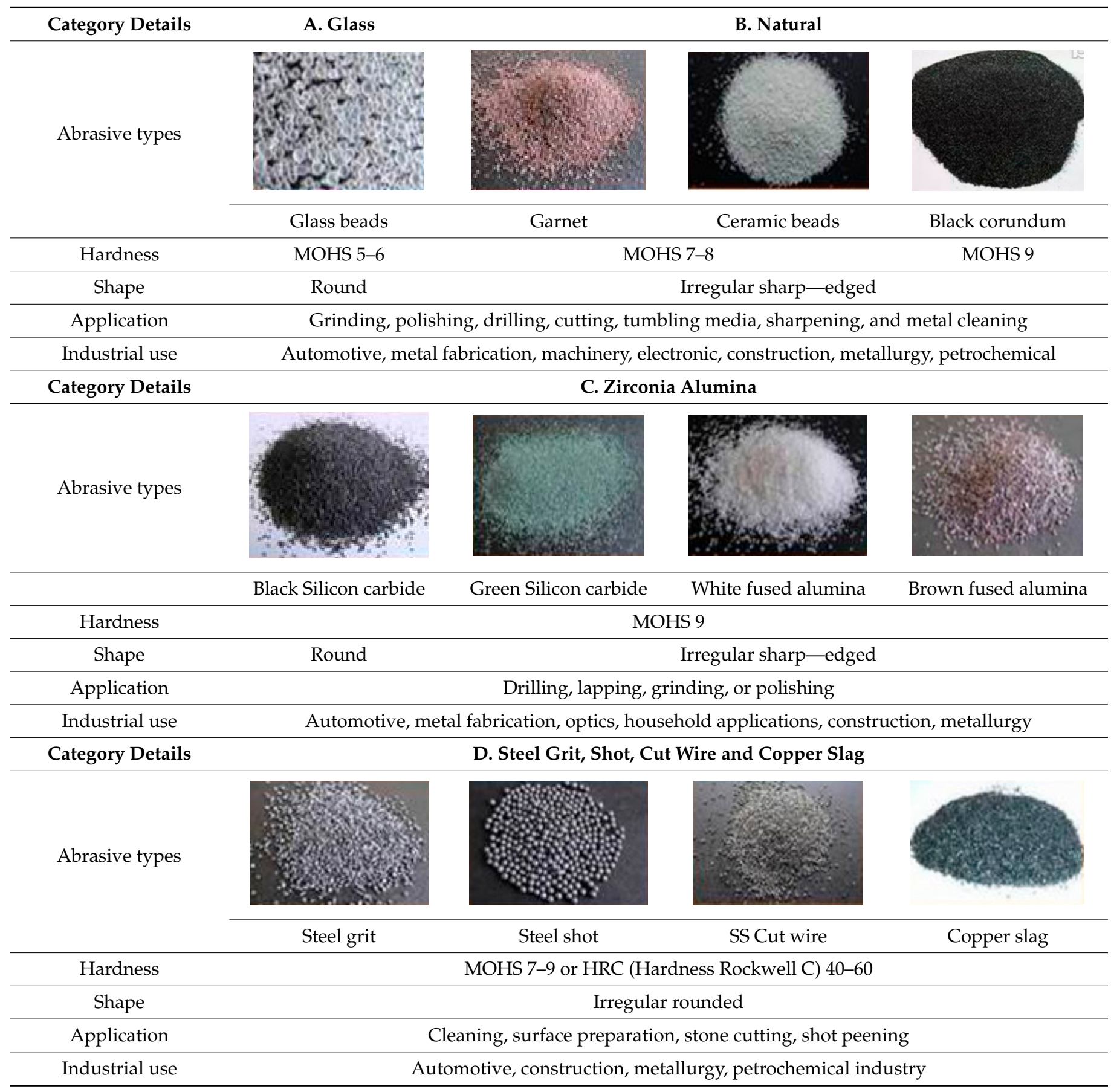


AWJM has capabilities in machining hard-to-cut materials because of its abrasive particles. Table 5 showed a representation of each abrasive category characteristic, such as particle shape, hardness, application, and industrial usage. The zirconia alumina group of abrasives indicates dominance in hardness.

Hlavacova et al. [89] have linearly machined high-carbon steel DIN norm No.1.2436 (CSN EN 19437) plate 61-mm-thick using seven different abrasives: Australian garnet, Ukraine garnet, olivine, corundum, chromite, and zirconium sized from 200 to $300 \mu \mathrm{m}$, and unsorted Australian garnet. They discovered that corundum, which was approximately equal to garnet, increased cutting speed at $20 \%$. Garnet has a comparatively low wear of focusing tubes when utilized [90]. A survey reported that $90 \%$ of users employ garnet as an abrasive type during AWJM applications [4]. Other reasons behind the high usage of garnet are attributed to its competitive price of approximately $0.48 € / \mathrm{Kg}$ [24]. However, the economic concern should be weighed against abrasive performance. Hence, the abrasive type is governed by the hardness of the workpiece [17]. Therefore, a harder workpiece requires a harder abrasive particle. In general, abrasive hardness directly exerts MRR and the depth of cut on the material; accordingly, a harder abrasive indicates higher MRR and DOC, leading to a higher machining efficiency.

Impacts of abrasive size: Abrasives come with varied sizes or mesh corresponding to their specific conditions or grades. The particle grain mass and volume directly impinge on kinetic energy, which influences AWJM output parameters [91]. Various mesh numbers with the corresponding mesh size and grade are summarized in Table 6.

Table 6. Abrasive mesh size and grade $[1,68,88,92]$.

\begin{tabular}{ccc}
\hline Mesh Number \# & Mesh in Microns $\mu \mathbf{m}$ & Grade \\
\hline $40-60$ & $250-400$ & Coarse \\
$80-100$ & $180-210$ & Medium coarse \\
$120-150$ & $90-105$ & Medium fine \\
$180-220$ & $70-88$ & Fine \\
240 upwards & $\leq 60$ & Very fine \\
\hline
\end{tabular}

The selection of an appropriate abrasive size and type depends on the hardness of the workpiece [92]. Thamizhvalavan et al. [93] have investigated the machining hybrid metal matrix which consists of $\mathrm{Al} 6063$ reinforced with boron carbide $\left(\mathrm{B}_{4} \mathrm{C}\right)$ and zirconium silicate $\left(\mathrm{ZrSiO}_{4}\right)$ in the form of particulates in the proportion of $5 \% \mathrm{~B}_{4} \mathrm{C}$ and $5 \% \mathrm{ZrSiO}_{4}$ using different type and mesh size of abrasives. They used aluminum oxide $\left(\mathrm{Al}_{2} \mathrm{O}_{3}\right)$ and garnet with varied mesh size numbers of 60,80 and 100. They concluded that a higher rate of material removal was achieved by using an abrasive type aluminum oxide $\left(\mathrm{Al}_{2} \mathrm{O}_{3}\right)$ with a mesh size number of 80 . Abrasives with all varied sizes showed the formation of striations in cut surfaces [93]. Moreover, Yuvaraj et al. [35] have analysed the effects of applying varying mesh sizes of garnet, including size 80, 100, and 120 in cutting AA5083-H32, where garnet with size number 80 produced a higher depth of cut, low kerf taper angle and surface roughness. Notwithstanding these studies, the abrasive mesh number is directly proportional to MRR, and a higher mesh size leads to higher roughness which results in a lower quality of cut surface.

Impacts of abrasive mass flow rate: In AWJ cutting operation, increasing the abrasive mass flow rate increases the erosion efficiency, containing a higher number of abrasives which relatively increases the depth of cut and decreases surface roughness value [36]. An increased rate of waterjet pressure denotes a parallel performance with abrasive flow rate [92]. Babu et al. [94] have presented a study of AWJ cutting process parameters performance in minimizing the surface roughness and kerf angle of AISI 1018 mild steel. They have observed that increasing the level of waterjet pressure, alongside with abrasive mass flow rate reduced the kerf taper angle and surface roughness. This achieved the minimum kerf geometries and less striation surface. Pawar et al. [44] have applied a moderate rate of abrasive mass flow. Mainly, a higher AFR directly leads to a higher 
MRR and DOC of machined material; however, it provides a conditional opposite effect in surface roughness and kerf taper angle, depending on the type of material.

\subsubsection{Nozzle System}

The nozzle system comprises the material type, nozzle diameter (ND), and orifice diameter (OD). The orifice ranges from 0.13 to $0.76 \mathrm{~mm}$ [95]. It is accountable for transforming water pressure into velocity; moreover, potential energy is converted into kinetic that is being transmitted to abrasive particles. The nozzle focuses the abrasive waterjet and leads it to the workpiece [6]. An illustration of a nozzle system working scheme is shown in Figure 5.

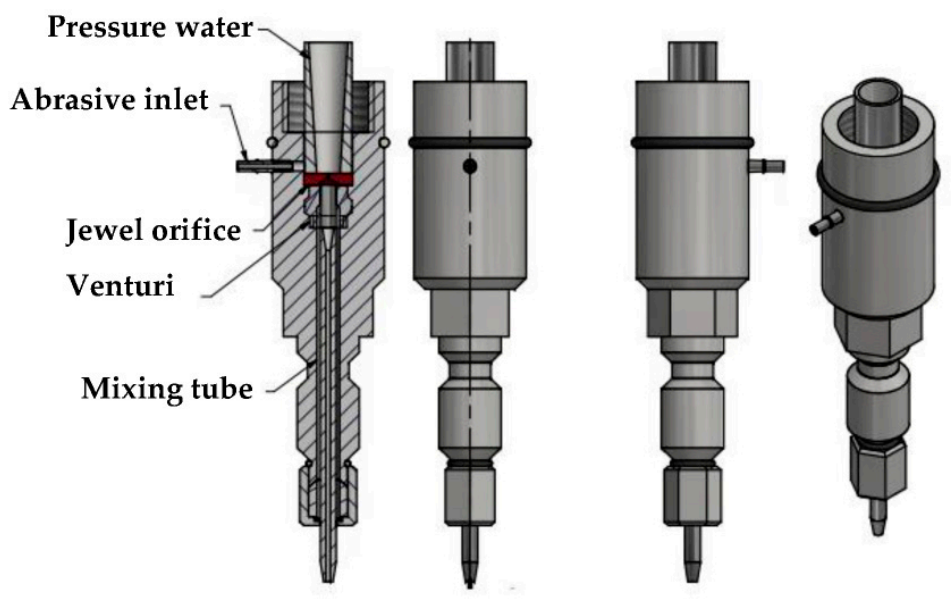

Figure 5. Nozzle system [92].

As illustrated in Figure 5, the waterjet pressure water travels at a high velocity and generates a Venturi effect or vacuum in the mixing chamber located beneath the orifice. A metered portion of abrasive particles enters through the abrasive inlet and is forced down with the waterjet stream in the mixing chamber [96]. The abrasive particles are mixed with the waterjet, creating an abrasive water jet. The nozzle is a vulnerable component of an abrasive waterjet machine and is commonly composed of silicon carbide, tungsten carbide cobalt, boron carbide, composite, and ceramic materials. Varied materials possess diverse properties that enable a nozzle to lengthen its utilization and wear [96]. In comparison to metals, ceramic nozzles $\left(\mathrm{SiC}, \mathrm{Al}_{2} \mathrm{O}_{3}, \mathrm{ZrO}_{2}, \mathrm{~B}_{4} \mathrm{C}\right.$ and $\left.\mathrm{Si}_{2} \mathrm{~N}_{4}\right)$ are universally used in line with mechanical properties, maximum hardness, a high melting point, and lesser resistance to heat shock. Furthermore, they can work 30 times longer than other carbon steel nozzles [91].

Impacts of nozzle and orifice diameter: Variation in the nozzle diameter and orifice leads to machining inconsistency due to the ascending airflow rate, jet deviating, and path size, hence impacting the material removal rate, surface roughness, and geometric accuracy in the broad-spectrum [6]. Furthermore, Kmec et al. [36] have investigated cutting austenitic steel AISI 304, which has recently been the most prevalent type of anticorrosion material in various industrial applications. They used different abrasive nozzle diameter sizes including $0.76 \mathrm{~mm}$ and $1.02 \mathrm{~mm}$. They conclude that the minimum surface roughness was achieved by using the smallest nozzle diameter of $0.76 \mathrm{~mm}$. Additionally, Mogul et al. [27] have studied surface roughness in cutting Titanium Ti6AL4V using an abrasive waterjet machine, where variations in the diameter ratio of the focusing nozzle and orifice were adopted. A different approach of ratio 3:1 nozzle and orifice diameter were employed in their experiments. The results indicate that increasing the waterjet orifice and focusing the nozzle diameter can minimize the surface roughness of the cut material. Later, Nandakumar, et al. [97] has examined the nozzle head oscillating method in AWJ cutting of aluminum hybrid composites. They concluded that a lower degree level of oscillation angle decreased the Kerf taper angle and surface roughness. Substantially, these previous 
researches indicate that the nozzle diameter and orifice influences the material removal rate, surface roughness, and geometric accuracy in a broad-spectrum.

\subsubsection{Cutting System}

These are the traverse speed, stand-off distance and jet impact angle. The traverse speed corresponds to the turning of a tank during machining, measured in $\mathrm{mm} / \mathrm{min}$. The standoff distance is the height from the endpoint of the nozzle up to the top surface of the target material, where it is indicated in mm. The jet impact angle is the angling of the jet towards a cutting level surface [6]. Recently, a relevant increase in productivity was obtained by utilizing AWJM with multiple cutting heads. There are two traverse systems that can be utilized simultaneously and independently to machine larger and multiple parts [5].

Impacts of traverse speed: Traverse speed variation has a significant effect on AWJM output parameters. Sasikumar et al. [98] reported that minimizing the kerf angle and surface roughness in AWJ cutting of hybrid aluminum 7075 metal matrix composites can be obtained by applying a low level of traverse speed and a high level of pressure. Their results are consistent with Gnanavelbabu et al. [77], who explored minimizing the kerf taper angle in cutting AA6061 using a low level of traverse speed. Ishfaq et al. [99] have distinguished that traverse speed was the most significant and impacting parameter for the material removal rate in AWJ cutting of stainless-clad steel workpieces. Additionally, the feed rate was revealed to be the most influential parameter in controlling the responses on surface roughness and kerf-angle in abrasive waterjet cutting of AISI 1018 with $5 \mathrm{~mm}$ thickness [94]. Moreover, Karmiris-Obratański et al. [100] explored AWJM multiple passes and achieved a higher depth of cut by utilizing a higher number of passes and higher-level traverse speed; hence, under particular conditions, the application of multiple passes can provide better results as compared with single pass machining. On the basis of these studies, the traverse speed is directly proportional to the material removal rate but inversely relative to the depth of cut, surface roughness, and kerf taper.

Impacts of stand-off distance: A higher distance from the nozzle exit and workpiece top surface results in decreasing velocity of the particles, which denotes a lower material removal rate, roughness, and kerf taper angle [92]. Kechagias et al. [81] have examined that decreased kerf width and roughness of cut parts can be obtained by applying a near standoff distance, a lower rate of traverse speed, and a smaller nozzle diameter at a higher material thickness when cutting steel sheets using an abrasive waterjet machine (TRIP $800 \mathrm{HR}-\mathrm{FH}$ and TRIP $700 \mathrm{CR}-\mathrm{FH})$. In summary, it has been found that a combination of a high-level standoff distance and high-rate traverse speed lowers the contact time of abrasive particles within the cutting process.

Impacts of jet impact angle: Varying the jet impingement angle leads to different impacts in AWJM output parameters depending on the hardness scale of a a workpiece [101]. For instance, Yuvaraj et al. [35] have proposed the importance of managing the jet impact angle to intensify AWJ cutting output responses. They reported that varying the impingement of the jet angle, along with using a different abrasive mesh size can affect the kerf width, taper ratio, and cut surface roughness when cutting AA5083-H32. An oblique jet angle of $70^{\circ}$ was shown to lead to lesser kerf taper ratio, roughness and striations. Furthermore, Kumar et al. [80] have conducted an experiment using a different metal, D2 Steel, and concluded that a jet impact angle of $70^{\circ}$ sustained better cut surface integrity. A larger degree of jet impingement angle results in a higher material removal rate, particularly in hard-to-cut materials; thus, an acute jet impact angle provides a precise cutting performance predominantly in soft materials [91]. In this paper, Figure 6 illustrates the statistics of the identified influential AWJM input process parameters within a range of publications from 2017-2020 [25-66]. Figure 6 illustrates the weighted distribution of the AWJ cutting input process parameters identified to be significant in AWJ cutting performance. 


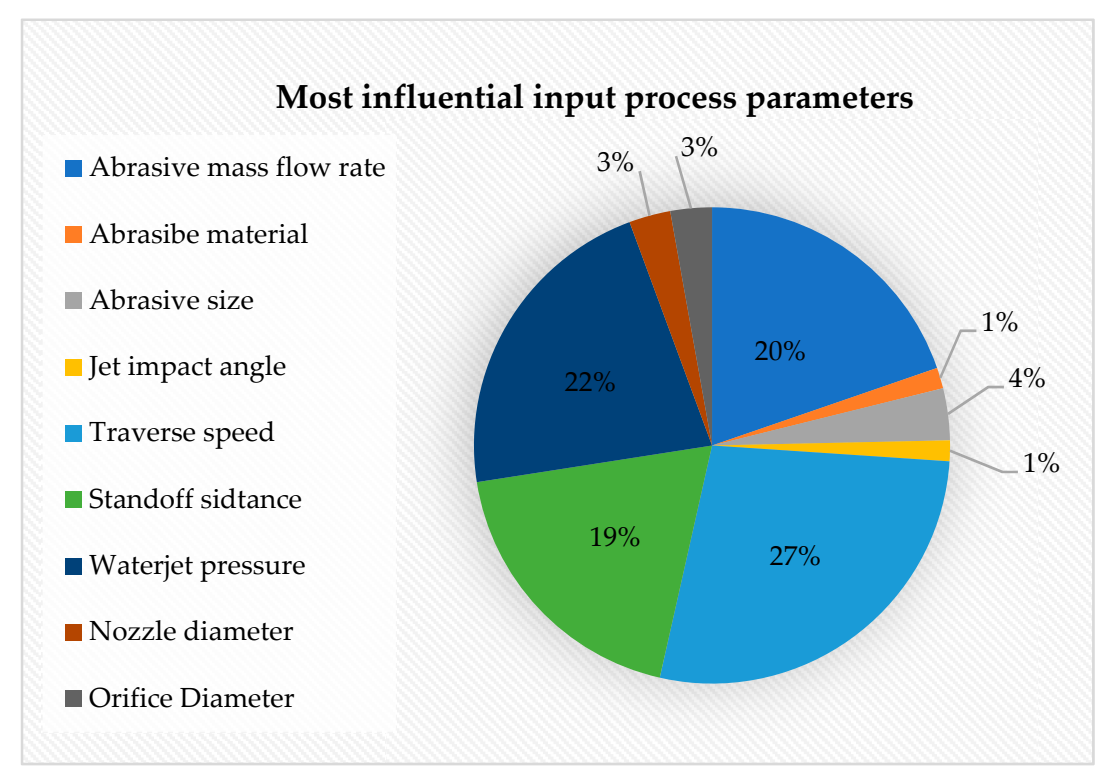

Figure 6. Survey of identified most influential AWJ cutting input process parameters reviewed publications from 2017 to 2020 [25-66].

Among these research findings, $27 \%$ proved that traverse speed is the most influential input parameter in the AWJ cutting process, followed by waterjet pressure, abrasive mass flow rate and standoff distance with a percentage contribution of 22, 20, and $19 \%$, respectively. There is a limited number of studies that considered the abrasive size, nozzle and orifice diameter, abrasive material and jet impact angle; hence, the impacts of these input parameters cannot be justified because of gaining less attention from researchers and having low usage in several experimental investigations. This can be considered as a potential area for future development and studies.

\subsection{Abrasive Waterjet Cutting Output Process Parameters}

The output process parameters of the AWJM include the material removal rate, depth of cut, kerf taper angle, kerf width, and surface roughness. These output parameters have been identified as quality attributes and are correlated with quality performance [102]. The depth of cut refers to the level of penetration of the workpiece. The material removal rate is determined by the quantity of removed material from a workpiece per unit time and is computed by the volume of removed material or from the difference in weight prior to and after machining. Furthermore, the material removal rate is a denotation of the machining rate performance. The kerf taper is the tapering angle resulting from AWJM and is the measurement by the ratio of the sum of kerf top width and kerf bottom and thickness of the workpiece. The taper width is the measurement of the top and bottom cut width of the target workpiece. The surface roughness is the scale of smoothness of the machined surface, denoting the precision of executed cutting processes. AWJ cutting processes involve several types of parametric variables that can impact machining performance. For this reason, it is necessary to use comprehensive equations or formulas when governing machining performance. Table 7 enumerates equations for determining output parameters.

Suitable values for the proper selection of process parameters must be determined and should be optimized for further development, which is discussed in the next section. 
Table 7. Output process parameters analytic equation.

\begin{tabular}{|c|c|c|c|c|}
\hline $\begin{array}{c}\text { Output Process } \\
\text { Parameter }\end{array}$ & \multicolumn{2}{|c|}{ Analytic Equations } & Unit of Measurement & $\begin{array}{l}\text { Equation Number } \\
\text { and Reference }\end{array}$ \\
\hline Depth of cut $(h t)$ & $h t=L \sin 25^{\circ}$ & $L$ inclined length & $\mathrm{mm}$ & Equation (1) [103] \\
\hline $\begin{array}{l}\text { Material removal } \\
\text { rate (MRR) }\end{array}$ & $\mathrm{MRR}=h t . W . v t$ & $\begin{array}{c}h t \text { is depth of cut, } \\
v t \text { is traverse speed, } \\
W \text { is kerf width } \\
\left(W_{t}-W_{b}\right) \\
W_{t} \text { is top kerf width }\end{array}$ & $\mathrm{mm}^{3} / \mathrm{min}$ & Equation (2) [77] \\
\hline Kerf taper angle (KTA) & $\mathrm{KTA} \theta=\arctan \frac{W_{t}-W_{b}}{2 h}$ & $\begin{array}{c}\text { and } W_{b} \text { is bottom kerf } \\
\text { width, } h \text { is thickness } \\
\text { of material }\end{array}$ & Degree $\left(^{\circ}\right)$ & Equation (3) [77] \\
\hline Surface roughness $\left(R_{a}\right)$ & $R_{a}=\frac{1}{l} \int_{0}^{l} y(x) d x$ & $\begin{array}{l}l \text { is sampling length, } y \\
\text { is profile height in a } \\
\text { defined point of } x \text {-axis }\end{array}$ & $\mu \mathrm{m}$ & Equation (4) [104] \\
\hline
\end{tabular}

\section{Abrasive Waterjet Cutting Process Parameters Improvements and Optimization}

Manufacturing industries are becoming more technically and economically attentive with advancements in the worldwide economy [105]. This demand produces a need for process parameter improvements and optimization.

\subsection{AWJ Cutting Process Parameters Improvements}

Abrasive waterjet cutting process parameters are factors that impact the effectiveness of machining performance. Defects such as the surface quality, kerf geometric inaccuracies and low material removal rate are directly correlated to transverse speed, standoff distance, waterjet pressure, and abrasive mass flow rate as well as material properties and material thickness. Therefore, nominating suitable values for these factors should be managed appropriately. Functional relations between these responses and input parameters of AWJ cutting were obtained and studied by many experimental results of numerous authors. Table 8 details a number of experimental investigations from recently published research, providing evaluations of correlations between input and output process parameters of AWJM, particularly in cutting operations. Based on the studies summarized in Table 8, water pressure at a high level provided a higher depth of cut and higher material removal rate $[33,58]$. A lower value of traverse speed ranging from 60 to $90 \mathrm{~mm} / \mathrm{min}$ was favorable in achieving a lower surface roughness, and a higher material removal rate and depth of cut $[30,33,78,106]$. 
Table 8. Impacts of the most influencing process parameters in AWJ cutting output parameters.

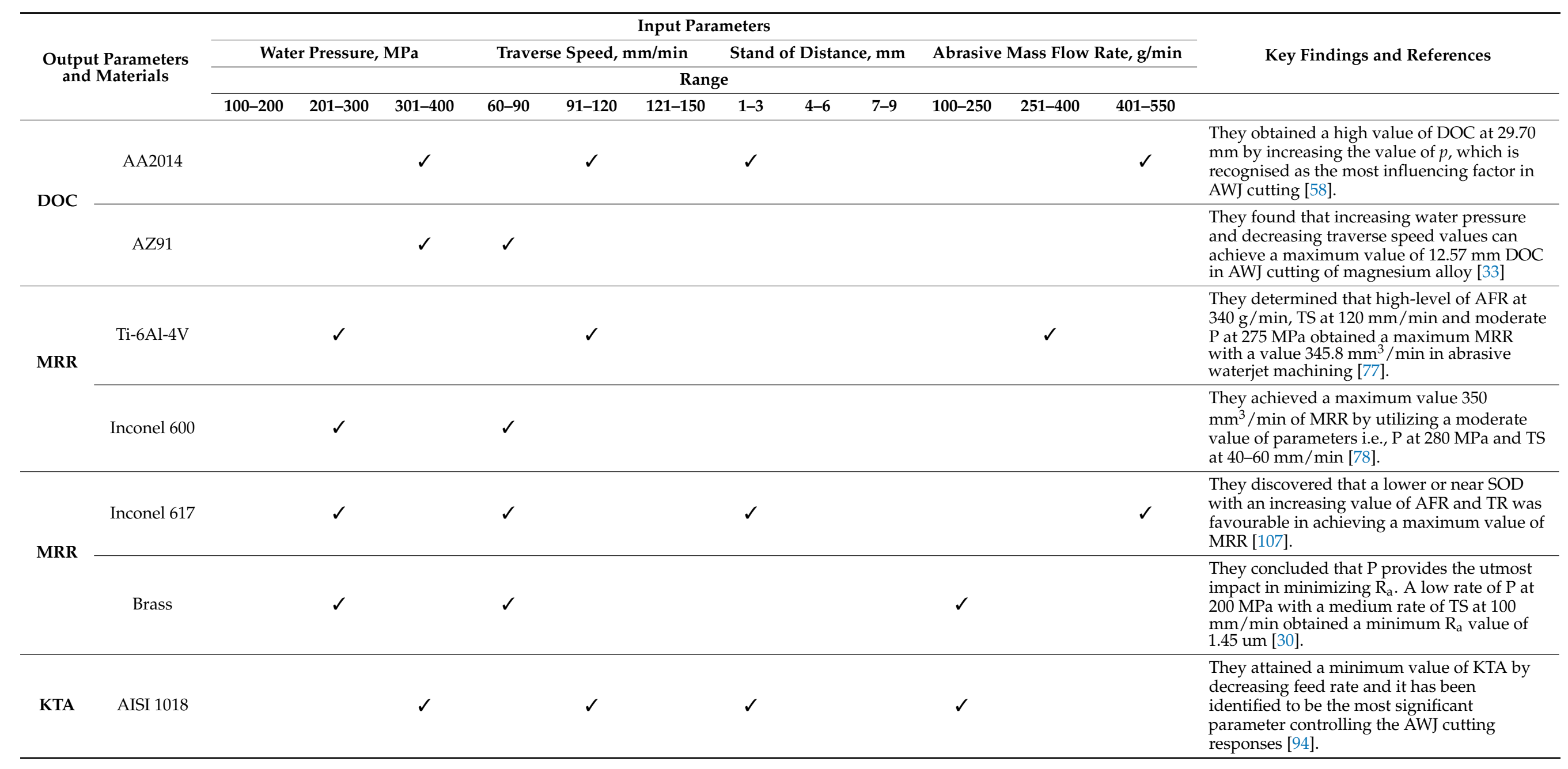


As presented in Table 8, a value of abrasive mass flow rate ranging to 100 to $250 \mathrm{~g} / \mathrm{min}$ achieved the minimum value of surface roughness and kerf taper angle $[30,106]$. Thus, it has been found that a nearer standoff distance provides a better AWJ cutting performance $[58,106]$.

\subsection{AWJ Cutting Process Parameters Optimisation}

Generally, optimization is utilized to achieve the minimum probable costs of cutting operations with a proper combination of process parameters considering indexes such as quality, productivity, and cost. Recently, an effective optimization technique, the Taguchi method, has become increasingly successful in optimizing some AWJM applications [108]. Several studies using the Taguchi method in their experimental work are shown in Table 9, mitigating the effectiveness of this technique.

Table 9. Several studies (2018 to 2020) in AWJ cutting carried out through the Taguchi method.

\begin{tabular}{|c|c|c|c|}
\hline Material & Input Parameter & Output Parameter & Key Findings and References \\
\hline Metal Matrix Composites & SOD, TS, AFR & $\mathrm{R}_{\mathrm{a}}$ & $\begin{array}{l}\text { Maneiah et al. [25] used Taguchi-L9 } \\
\text { orthogonal array in their experimental } \\
\text { investigations. The results showed that } \\
\text { the essential parameters in reducing } R_{a} \\
\text { were TS and AFR. }\end{array}$ \\
\hline Ti6AL4V & P, TS, AFR, ND, OD & $\mathrm{R}_{\mathrm{a}}, \mathrm{DOC}$ & $\begin{array}{l}\text { Mogul et al. [27] worked in the } \\
\text { prediction of cutting depth by using the } \\
\text { Taguchi method. It was proven that TS } \\
\text { was the most influencing parameter for } \\
\text { a higher depth of cut. }\end{array}$ \\
\hline Inconel 625 & $\mathrm{P}, \mathrm{AFR}, \mathrm{SOD}$ & KTA & $\begin{array}{l}\text { Jeykrishnan et al. [29] employed } \\
\text { Taguchi's technique in this study, and it } \\
\text { was observed that P played a } \\
\text { significant role in lower } \\
\text { kerf taper angle. }\end{array}$ \\
\hline Brass & P, TS, AFR & $\mathrm{R}_{\mathrm{a}}, \mathrm{MRR}$ & $\begin{array}{l}\text { By utilizing Taguchi's L9 orthogonal } \\
\text { array, Marichamy et al. [30] proved the } \\
\text { feasibility of utilising an abrasive } \\
\text { waterjet machine in cutting brass } \\
\text { material. They concluded that } \\
\text { increasing P, TS, and AFR can minimise } \\
\mathrm{R}_{\mathrm{a}} \text { and maximise MRR. }\end{array}$ \\
\hline AZ91 Magnesium alloy & $\mathrm{P}, \mathrm{TS}$ & DOC & $\begin{array}{l}\text { Niranjan et al. [33] examined influence } \\
\text { of process parameters in the depth of } \\
\text { cut through the Taguchi experimental } \\
\text { design of the L9 orthogonal array. The } \\
\text { result showed that a higher DOC could } \\
\text { be obtained with high P and low TS. }\end{array}$ \\
\hline Ti-6Al-4V and Inconel 825 & $\mathrm{P}, \mathrm{SOD}, \mathrm{AFR}$ & $\mathrm{R}_{\mathrm{a}}$ & $\begin{array}{l}\text { Rajamanickam et al. [34] achieved a } \\
\text { higher MRR for Ti-6Al-4V at a value of } \\
3.132 \mathrm{gm} / \mathrm{min} \text { and } 3.246 \mathrm{gm} / \mathrm{min} \text { for } \\
\text { Inconel } 825 \text { by utilising an } \\
\text { experimental Taguchi approach. }\end{array}$ \\
\hline
\end{tabular}

Taguchi is a technique applied for improving quality performance depending merely on process parameters. Taguchi's orthogonal array is useful in establishing impacts created by these cutting parameters with two or more mixed levels, which lessens the number of required experimental trials [109]. Aside from the Taguchi methodology, there are several other tools applied to quantify the correlation between AWJM input and output parameters. Table 10 enlisted several noteworthy research studies that have been published, which 
focused on different experimental and simulation studies to achieve the optimum degree of these process parameters.

Table 10. A list of several studies (2017 to 2020) with a diverse optimization technique in AWJ cutting process.

\begin{tabular}{|c|c|c|c|c|}
\hline Material & Input Parameter & Output Parameter & Optimisation Techniques & Key Findings and References \\
\hline AA5083-H32 & P, JIA, AS & $\mathrm{R}_{\mathrm{a}}, \mathrm{KTA}, \mathrm{KTW}, \mathrm{KBW}$ & Fuzzy TOPSIS method & $\begin{array}{l}\text { Yuvaraj et al. [35] employed an } \\
\text { optimisation technique to select optimal } \\
\text { values of input parameters, specifically, } \mathrm{P} \\
\text { of } 150 \mathrm{MPa} \text {, AS of \#80, and JIA of } 70^{\circ} \text {. They } \\
\text { concluded that oblique JIA improved the } \\
\text { cutting performance of abrasive } \\
\text { waterjet machine. }\end{array}$ \\
\hline Inconel 718 & $\mathrm{P}, \mathrm{SOD}, \mathrm{AFR}$ & $\mathrm{R}_{\mathrm{a}}, \mathrm{MRR}, \mathrm{KTA}$ & $\begin{array}{c}\text { VlseKriterijumska } \\
\text { Optimizacija I } \\
\text { Kompromisno Resenje in } \\
\text { Serbian (VIKOR) method }\end{array}$ & $\begin{array}{l}\text { Samson et al. [37] distinguished the } \\
\text { optimised parameter combinations of } 180 \\
\text { MPa P, } 0.42 \mathrm{~kg} / \mathrm{min} \text { of AFR and } 2 \mathrm{~mm} \text { SOD. } \\
\text { They concluded that the lower standoff } \\
\text { distance was favourable, as it increased the } \\
\text { material removal rate. }\end{array}$ \\
\hline Inconel 718 & P, TS, AFR, AM & $\mathrm{R}_{\mathrm{a}}$ & $\begin{array}{l}\text { Response surface } \\
\text { methodology-Box } \\
\text { Behnken Method } \\
\text { (RSM-BBM) }\end{array}$ & $\begin{array}{l}\text { Kumar et al. [42] obtained a surface } \\
\text { roughness within the range of } 2.75 \text { to } \\
4.94 \mu \mathrm{m} \text { with the optimal level of } \mathrm{P} \text { at } \\
40,757 \mathrm{psi} \text {, AFR at } 1.25 \mathrm{lb} / \mathrm{min}, \mathrm{SOD} \text { at } \\
0.6 \mathrm{~mm} \text { and TS at } 20 \mathrm{~mm} / \mathrm{min} \text {. They } \\
\text { discovered that TS and AFR were the most } \\
\text { important parameters in the machining of } \\
\text { Inconel } 718 \text {. }\end{array}$ \\
\hline Al7075/TiB2 & $\begin{array}{l}\text { P, TS, AFR, AS, } \\
\text { SOD, OD }\end{array}$ & $\mathrm{R}_{\mathrm{a}}, \mathrm{MRR}, \mathrm{KTA}$ & $\begin{array}{l}\text { Taguchi DEAR (Data } \\
\text { Envelopment Analysis } \\
\text { Based Ranking) } \\
\text { Methodology }\end{array}$ & $\begin{array}{l}\text { Manoj et al. [43] discovered that waterjet } \\
\text { pressure has the highest influence in AWJ } \\
\text { cutting responses such as MRR, Ra and } \\
\text { KTA. The optimal process parameters } \\
\text { combination achieved are P of ( } 280 \mathrm{MPa}) \\
\text { TS of } 345 \mathrm{~mm} / \mathrm{min} \text { and SOD of } 4 \mathrm{~mm} \text {. }\end{array}$ \\
\hline AA631-T6 & TS, SOD, AFR & $\mathrm{R}_{\mathrm{a}}, \mathrm{MRR}, \mathrm{KTA}$ & Jaya algorithm (JA) & $\begin{array}{l}\text { Rao et al. [110] utilised single-objective } \\
\text { (SAO) and multi-objective (MOJA) to } \\
\text { achieve better cutting performance. The } \\
\text { maximum value of MRR obtained by the } \\
\text { MO-Jaya algorithm was } 6769.6 \mu \mathrm{m} 3 / \mu \mathrm{s}, \\
\text { and the minimum value of Ra obtained by } \\
\text { the MO-Jaya algorithm was } 2.7002 \mu \mathrm{m} \text {. }\end{array}$ \\
\hline Inconel 617 & SOD, P, TS, AFR & MRR, Geometric accuracy & $\begin{array}{l}\text { Weighted principal } \\
\text { components analysis } \\
\text { (WPCA) }\end{array}$ & $\begin{array}{l}\text { Nair et al. [107] studied MRR and } \\
\text { geometric accuracy considering SOD, P, TS, } \\
\text { AFR as input parameters. They determined } \\
\text { optimal factors and observed that waterjet } \\
\text { pressure was a less significant factor as the } \\
\text { minimum setting was adequate enough to } \\
\text { execute the machining process. }\end{array}$ \\
\hline AA 6061 & $\begin{array}{l}\text { P, TS, AFR, SOD, } \\
\text { ND }\end{array}$ & $\mathrm{R}_{\mathrm{a}}, \mathrm{MRR}, \mathrm{KTA}$ & $\begin{array}{c}\text { Grey wolf } \\
\text { optimizer (GWO) }\end{array}$ & $\begin{array}{l}\text { Chakraborty et al. [47] attained the } \\
\text { optimum parametric settings, which were } \\
\text { P of } 310 \mathrm{MPa} \text {, TS of } 0.05 \mathrm{~mm} / \mathrm{s} \text {, AFR of } \\
11.5 \mathrm{~g} / \mathrm{s} \text {, and nozzle tilted in } 115^{\circ}, \text { by using } \\
\text { the GWO method. This combination } \\
\text { resulted in an MRR of } 6769.597 \mu \mathrm{m}^{3} / \mu \mathrm{s} \text {. }\end{array}$ \\
\hline Ti-6Al-4V & P, TS, SOD, AFR & DOC & $\begin{array}{l}\text { Artificial Neural } \\
\text { Network (ANN) }\end{array}$ & $\begin{array}{l}\text { Selvan et al. [72] concluded that SOD and } \\
\text { TS are inversely proportional to DOC. }\end{array}$ \\
\hline
\end{tabular}

Yuvaraj and Kumar [35] applied the fuzzy TOPSIS (Technique for Order Preference by Similarities to Ideal Solution) method as an optimization technique to attain better AWJ cutting performance with AA5083-H32. They considered the pressure, jet impact angle, and abrasive size as input parameters to achieve minimum values of surface roughness, kerf taper angle, and kerf width. Furthermore, they also used an additional algorithm method, the Grey-fuzzy method, to optimize AWJM process parameters for different materials like glass fiber reinforced polymer [35].

Samson et al. [37] have obtained optimal values of AWJM process parameters for machining Inconel 718, utilizing the VlseKriterijumska Optimizacija Kompromisno Resenje in Serbian (VIKOR) method. The researchers advanced the VIKOR method by employing an analytic hierarchy process (AHP) to convey the weight of the comparative significance 
of the aspects. This involved a multi-criterion decision-making (MCDM) system suitable for selecting feasible or almost ideal solutions from a set of presented alternatives [111]. The results showed that low pressure, abrasive mass flow rate, and standoff distance can minimize the kerf taper angle and roughness and maximize the material removal rate.

A hybrid response surface and Box-Behnken methodology (RSM-BBD), Kumar et al. [42] have shown the influence of pressure, traverse speed, abrasive mass flow rate, and abrasive particle in determining a tolerable level of roughness for cutting Inconel 718 and in formulating a mathematical model for predicting results. Confirmation experiments have validated the precision of these developed models.

Manoj et al. [43] have employed a Taguchi-DEAR methodology to evaluate AWJ cutting process parameters-i.e., waterjet pressure, transverse speed and standoff distance for $\mathrm{TiB}_{2}$ particles in reinforced Al7075 composite materials. They anticipated higher levels of material removal rate and lower levels of surface roughness and taper angle. A customary of results of investigation were plotted to determine combinations of suitable process parameters based on a multi-response performance index (MRPI).

Rao et al. [110] considered the traverse speed, standoff distance, and abrasive mass flow rate as input parameters of an AWJ cutting process of AA631-T6. The results of material removal, roughness, and taper angle were considered against the application of the Jaya algorithm (JO). This optimization algorithm can be used to solve constrained and unconstrained conditions, to achieve an optimum alternative and avoid the worst ones [112].

Nair and Kumanan [107] used weighted principal components analysis (WPCA) to optimize AWJM process parameters in machining Inconel 617. The measured performance indicators included the material removal rate (MRR) and geometric accuracy. The WPCA method uses internal test and training samples to calculate the 'weighted' covariance matrix. The theoretical basis of WPCA is determined through a 'weighted' covariance matrix. Moreover, WPCA highlights training samples similar to the test sample and lessens the impact of other training samples [113].

Chakraborty and Mitra [47] have carried out the grey wolf optimizer (GWO) technique for AWJ cutting of AA6061, considering multiple objectives including material removal rate, surface roughness, overcut and taper. The GWO algorithm is a non-dominated set of Pareto solutions whose optimization imitates the hunting activities of grey wolves. A distinct advantage of GWO is that it identifies the best possible solution and stores this through the aid of social hierarchy.

Selvan et al. [72] developed mathematical equations using the regression investigation method (RIM) artificial neural network (ANN) procedures to select the optimum parameters. ANN is a computer-aided program mimicking the way the human brain manages information, collecting information by identifying outlines and interactions in data, acquired through experience other than from programming [39]. They observed that the developed model using ANN can predict AWJ cutting responses with at least $90 \%$ accuracy. This can be further used in predicting the output for different parameter conditions such as waterjet pressure, traverse speed, standoff distance, and abrasive mass flow rate for AWJ cutting of various materials.

This review section outlined several optimization techniques of AWJ cutting operations in diverse experimental conditions with the objective of attaining higher productivity and better quality.

\section{Conclusions and Potential Future Scope of Study}

There has been an exponential increase in the demand for AWJM in various manufacturing industries, which is why further study of performance enhancement is necessary. This review presents an overview of recent developments and progress made in applications of AWJ cutting, which are valuable for future studies. Based on the above-mentioned reviews and discussions, the following conclusion and potential future scopes of study have been identified: 


\subsection{Conclusions}

- The intensive review of the trend of recently published research studies has revealed that aluminium and other metal workpieces gained $53 \%$ of the attention in exploring AWJM application improvements. A total of $27 \%$ of recent studies have proved that traverse speed greatly impacts abrasive waterjet (AWJ) cutting performance, followed by abrasive mass flow rate and waterjet pressure with statistics of $22 \%$ and $20 \%$, respectively. Garnet with a hardness scale of MOHS 7-8 and a mesh size of \#80 at $180 \mu \mathrm{m}$ gained $90 \%$ utilisation in AWJM applications due to its better performance and competitive price.

- AWJ cutting of hard-to-cut workpieces such as metallic materials including tungsten carbide, tool steel, and Inconel alloys have demonstrated distinct characteristics such as the fast speed at a rate of 2 to $3 \mathrm{~mm}^{3} / \mathrm{s}$, versatility in cutting with thickness ranging from $\leq 304.8 \mathrm{~mm}$, the ability to machine complicated shapes, and environmentally sustainable qualities. These characteristics explain their wide range of current applications across various industries.

- Cutting metallic materials with low machinability, i.e., stainless steel, Inconel and titanium, can attain lower surface roughness, higher depth of cut and material removal rate at a waterjet pressure ranging from 201 to $300 \mathrm{MPa}$. A traverse speed ranging from 60 to $90 \mathrm{~mm} / \mathrm{min}$, abrasive mass flow rate of 401 to $500 \mathrm{~g} / \mathrm{min}$, and stand-off distance ranging from 1.0 to $3.0 \mathrm{~mm}$ were established to achieve a lower surface roughness, lower kerf taper angle, and higher material removal rate applicable to various metals. Different optimisation techniques such as weighted principal components analysis (WPCA), surface and Box-Behnken methodology (RSM-BBD) and grey wolf optimiser (GWO) were employed and proved to be notably efficient in defining the optimum values of process parameters.

\subsection{Potential Further Study}

- $\quad$ AWJ cutting has acquired high interest in improving process performance at specific input parameter conditions. Hence, limited studies considered other parameters such as the jet impact angle, abrasive, and nozzle sizes. A further study on the impacts of these mentioned input parameters in AWJ cutting of various materials with different thicknesses can be considered for future improvements.

- Based on a review of past literature, numerous research studies and experiments have been conducted to evaluate the difference between the straight-slit and linear cutting process of AWJMs. Nonetheless, limited reports present AWJM performance in contour cutting. Thus, the cuttings of complex and complicated geometries are more regularly applied in manufacturing industries rather than straight-slit or linear cutting. Undertaking an empirical and analytical study of the effects of the process parameters in AWJ contour cutting would be important to various manufacturing processes in the fabrication industry.

- A prolific number of works have been fulfilled in predicting and monitoring AWJ cutting performance and responses in terms of quality and productivity. Its effectiveness in machining cost and intelligent process controlling are two areas that can be studied further to determine future developments.

Author Contributions: Conceptualization: M.T.-R., J.M.L.; investigation and writing original draft: J.M.L.; review and supervision: M.T.-R. and A.V.; Editing and project administration: M.A. and J.M.L. All authors have read and agreed to the published version of the manuscript.

Funding: This research received no external funding.

Institutional Review Board Statement: Not applicable.

Informed Consent Statement: Not applicable.

Data Availability Statement: Not applicable. 
Acknowledgments: The authors would like to thank the School of Engineering, Edith Cowan University, Australia, for providing and administering the needed requirements in accomplishing this research.

Conflicts of Interest: The authors declare no conflict of interest.

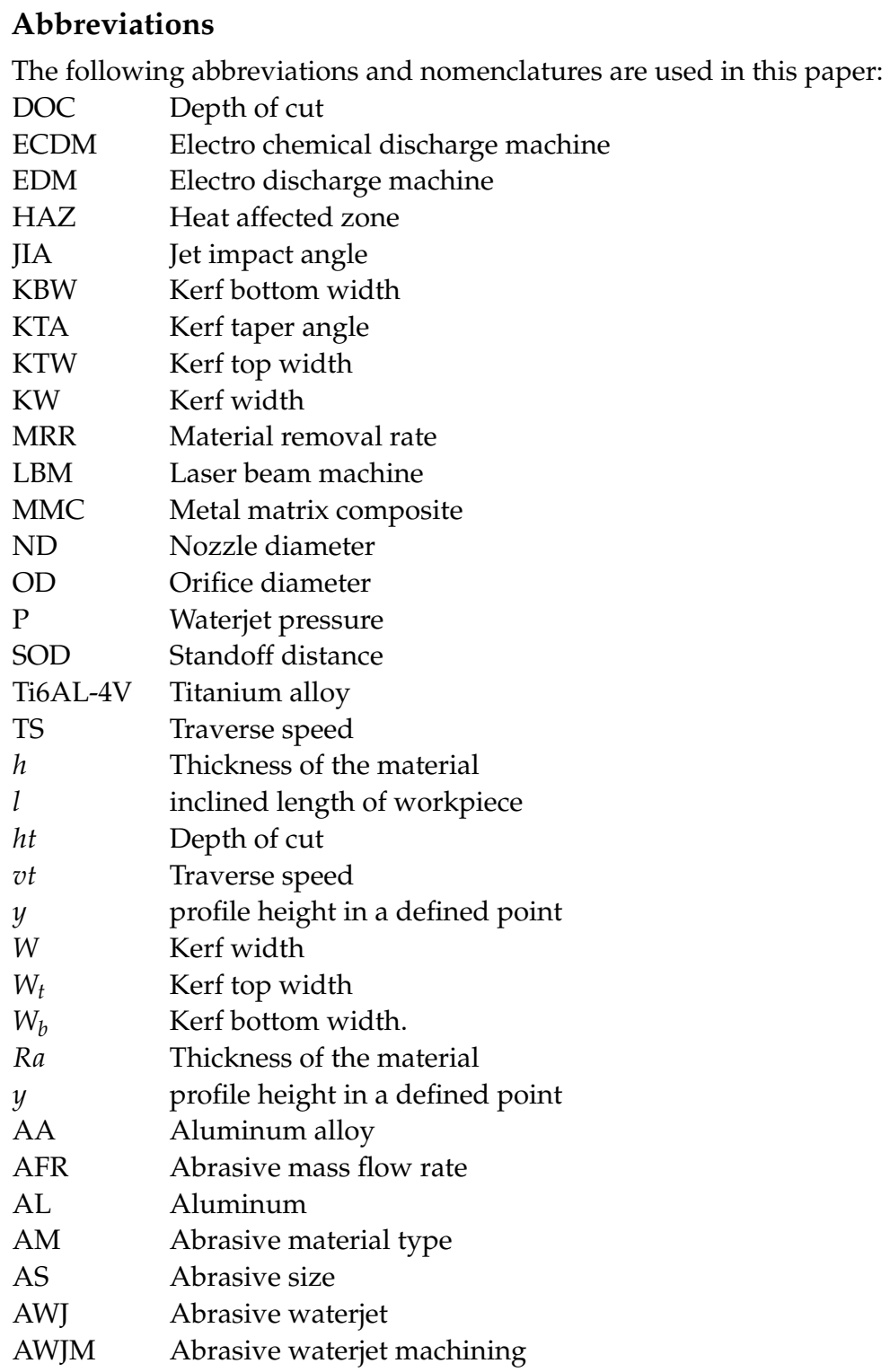

\section{References}

1. Alsoufi, M.S. State-of-the-Art in Abrasive Water Jet Cutting Technology and the Promise for Micro-and Nano-Machining. Int. J. Mech. Eng. Appl. 2017, 5, 1-14. [CrossRef]

2. Gupta, K. Introduction to Abrasive Water Jet Machining. In Abrasive Water Jet Machining of Engineering Materials; Springer: Berlin/Heidelberg, Germany, 2020; pp. 1-11.

3. Liu, X.; Liang, Z.; Wen, G.; Yuan, X. Waterjet machining and research developments: A review. Int. J. Adv. Manuf. Technol. 2019, 102, 1257-1335. [CrossRef]

4. Natarajan, Y.; Murugesan, P.K.; Mohan, M.; Khan, S.A.L.A. Abrasive Water Jet Machining process: A state of art of review. J. Manuf. Process. 2020, 49, 271-322. [CrossRef]

5. Liu, H. "7M" Advantage of Abrasive Waterjet for Machining Advanced Materials. J. Manuf. Mater. Process. 2017, 1, 11. [CrossRef]

6. Saravanan, S.; Vijayan, V.; Suthahar, S.T.J.; Balan, A.V.; Sankar, S.; Ravichandran, M. A review on recent progresses in machining methods based on abrasive water jet machining. Mater. Today Proc. 2020, 21, 116-122. [CrossRef]

7. Liu, H.; Schubert, E. Micro abrasive-waterjet technology. In Micromachining Techniques for Fabrication of Micro and Nano Structures; InTechOpen: London, UK, 2012; pp. 205-233. 
8. Singh, P.; Pramanik, A.; Basak, A.; Prakash, C.; Mishra, V. Developments of non-conventional drilling methods-A review. Int. J. Adv. Manuf. Technol. 2020, 106, 2133-2166. [CrossRef]

9. Sureban, R.; Kulkarni, V.N.; Gaitonde, V. Modern Optimization Techniques for Advanced Machining Processes-A Review. Mater. Today Proc. 2019, 18, 3034-3042. [CrossRef]

10. Nguyen, T.; Wang, J. A review on the erosion mechanisms in abrasive waterjet micromachining of brittle materials. Int. J. Extrem. Manuf. 2019, 1, 012006. [CrossRef]

11. Mieszala, M.; Torrubia, P.L.; Axinte, D.A.; Schwiedrzik, J.J.; Guo, Y.; Mischler, S.; Michler, J.; Philippe, L. Erosion mechanisms during abrasive waterjet machining: Model microstructures and single particle experiments. J. Mater. Process. Technol. 2017, 247, 92-102. [CrossRef]

12. Hlaváčová, I.M.; Sadílek, M.; Váňová, P.; Szumilo, Š.; Tyč, M. Influence of steel structure on machinability by abrasive water jet. Materials 2020, 13, 4424. [CrossRef]

13. Kowsari, K.; Nouraei, H.; James, D.; Spelt, J.; Papini, M. Abrasive slurry jet micro-machining of holes in brittle and ductile materials. J. Mater. Process. Technol. 2014, 214, 1909-1920. [CrossRef]

14. Ruiz-Garcia, R.; Ares, P.F.M.; Vazquez-Martinez, J.M.; Gomez, J.S. Influence of Abrasive Waterjet Parameters on the Cutting and Drilling of CFRP/UNS A97075 and UNS A97075/CFRP Stacks. Materials 2019, 12, 107. [CrossRef] [PubMed]

15. Supriya, S.; Srinivas, S. Machinability studies on stainless steel by abrasive water jet-Review. Mater. Today Proc. 2018, 5, 2871-2876. [CrossRef]

16. Rajurkar, K.P.; Sundaram, M.M.; Malshe, A.P. Review of Electrochemical and Electrodischarge Machining. Procedia Cirp 2013, 6, 13-26. [CrossRef]

17. Rajurkar, K.P.; Hadidi, H.; Pariti, J.; Reddy, G.C. Review of Sustainability Issues in Non-traditional Machining Processes. In Proceedings of the International Conference on Sustainable Materials Processing and Manufacturing (SMPM 2017), Kruger, South Africa, 23-25 January 2017; pp. 714-720. [CrossRef]

18. Akkurt, A. Surface properties of the cut face obtained by different cutting methods from AISI 304 stainless steel materials. Indian J. Mater. Sci. 2009, 16, 373-384.

19. Krajcarz, D. Comparison Metal Water Jet Cutting with Laser and Plasma Cutting. In Proceedings of the 24th Daaam International Symposium on Intelligent Manufacturing and Automation, Zadar, Croatia, 23-26 October 2013; Volume 69, pp. 838-843. [CrossRef]

20. Chaturvedi, C.; Rao, P.S. Some Technical Issues and Critical Assessment of Abrasive Water Jet Machining (AWJM) Process. Int. J. Innov. Technol. Explor. Eng. 2020, 9, 39520. [CrossRef]

21. Rakshit, R.; Das, A.K. A review on cutting of industrial ceramic materials. Precis. Eng. 2019, 59, 90-109. [CrossRef]

22. Kovacevic, R.; Mohan, R.; Beardsley, H.E. Monitoring of Thermal Energy Distribution in Abrasive Waterjet Cutting Using Infrared Thermography. J. Manuf. Sci. Eng. 1996, 118, 555-563. [CrossRef]

23. Babu, M.K.; Chetty, O.K. A study on recycling of abrasives in abrasive water jet machining. Wear 2003, 254, 763-773. [CrossRef]

24. Schramm, A.; Morczinek, F.; Götze, U.; Putz, M. Technical-economic evaluation of abrasive recycling in the suspension fine jet process chain. Int. J. Adv. Manuf. Technol. 2020, 106, 981-992. [CrossRef]

25. Maneiah, D.; Shunmugasundaram, M.; Reddy, A.R.; Begum, Z. Optimization of machining parameters for surface roughness during abrasive water jet machining of aluminium/magnesium hybrid metal matrix composites. Mater. Today Proc. 2020, 27, 1293-1298. [CrossRef]

26. Tripathi, D.R.; Vachhani, K.H.; Kumari, S.; Abhishek, K. Experimental investigation on material removal rate during abrasive water jet machining of GFRP composites. Mater. Today Proc. 2020, 26, 1389-1392. [CrossRef]

27. Mogul, Y.I.; Nasir, I.; Myler, P. Investigation and optimization for depth of cut and surface roughness for control depth milling in Titanium Ti6AL4V with abrasive water jet cutting. Mater. Today Proc. 2020, 28, 604-610. [CrossRef]

28. Naik, M.B.; Srikanth, D.; Rao, M.S. Abrasive Jet Machining on Soda lime Glass-An experimental investigation. Int. J. Res. Publ. 2020, 44, 887 .

29. Jeykrishnan, J.; Ramnath, B.V.; Vignesh, S.S.; Sridharan, P.; Saravanan, B. Optimization of Process Parameters in Abrasive Water Jet Machining/Cutting (AWJM) of Nickel Alloy using Traditional Analysis to Minimize Kerf Taper Angle. Mater. Today Proc. 2019, 16, 392-397. [CrossRef]

30. Marichamy, S.; Ravichandran, M.; Stalin, B.; Babu, S.B. Optimization of abrasive water jet machining parameters for $\alpha-\beta$ brass using Taguchi methodology. FME Trans. 2019, 47, 116-121. [CrossRef]

31. Kumar, P.; Tank, B.; Kant, R. Experimental investigation on abrasive waterjet machining of fibre vinyl ester composite. J. Manuf. Eng. 2019, 14, 134-138. [CrossRef]

32. Srikanth, D.V.; Rao, M.S. Application of Taguchi \& Response surface methodology in Optimization for machining of ceramics with abrasive jet machining. Mater Today Proc. 2015, 2, 3308-3317. [CrossRef]

33. Niranjan, C.; Srinivas, S.; Ramachandra, M. An experimental study on depth of cut of AZ91 Magnesium Alloy in abrasive water jet cutting. Mater. Today Proc. 2018, 5, 2884-2890. [CrossRef]

34. Rajamanickam, S.; Manjunathan, R.; Mariyappan, K.; Aravindh, S. Comparative analysis of MRR on abrasive water jet machining parameters over aerospace alloys: Inconel 825 \& Ti-6Al-4V. Int. J. Pure Appl. Math. 2018, 118, 727-733.

35. Yuvaraj, N.; Kumar, M.P. Optimisation of abrasive water jet cutting process parameters for AA5083-H32 aluminium alloy using fuzzy TOPSIS method. Int. J. Mach. Mach. Mater. 2018, 20, 118-140. 
36. Kmec, J.; Gombár, M.; Harničárová, M.; Valíček, J.; Kušnerová, M.; Křŕž, J.; Kadnár, M.; Karková, M.; Vagaská, A. The Predictive Model of Surface Texture Generated by Abrasive Water Jet for Austenitic Steels. Appl. Sci. 2020, 10, 3159. [CrossRef]

37. Samson, R.M.; Rajak, S.; Kannan, T.D.B.; Sampreet, K. Optimization of Process Parameters in Abrasive Water Jet Machining of Inconel 718 Using VIKOR Method. J. Inst. Eng. 2020, 101, 579-585. [CrossRef]

38. Senthilkumar, T.; Muralikannan, R.; Kumar, S.S. Surface morphology and parametric optimization of AWJM parameters using GRA on aluminum HMMC. Mater. Today Proc. 2020, 22, 410-415. [CrossRef]

39. Madara, S.R.; Pillai, S.R. Modelling of surface roughness in abrasive waterjet cutting of Kevlar 49 composite using artificial neural network. Mater. Today Proc. 2020. [CrossRef]

40. Jagadish; Bhowmik, S.; Ray, A. Prediction of surface roughness quality of green abrasive water jet machining: A soft computing approach. J. Intell. Manuf. 2019, 30, 2965-2979. [CrossRef]

41. Brucely, Y.; Jai Aultrin, K.S.; Jaison, D. Using Genetic Algorithm Optimizing the Cutting Parameters of AWJM Process for Aluminium 6061 Alloy. Int. J. Recent Trends Eng. Res. 2019, 5, 48-56. [CrossRef]

42. Kumar, A.; Singh, H.; Kumar, V. Study the parametric effect of abrasive water jet machining on surface roughness of Inconel 718 using RSM-BBD techniques. Mater. Manuf. Process. 2018, 33, 1483-1490. [CrossRef]

43. Manoj, M.; Jinu, G.R.; Muthuramalingam, T. Multi Response Optimization of AWJM Process Parameters on Machining TiB2 Particles Reinforced Al7075 Composite Using Taguchi-DEAR Methodology. Silicon 2018, 10, 2287-2293. [CrossRef]

44. Pawar, P.J.; Vidhate, U.S.; Khalkar, M.Y. Improving the quality characteristics of abrasive water jet machining of marble material using multi-objective artificial bee colony algorithm. J. Comput. Des. Eng. 2018, 5, 319-328. [CrossRef]

45. Rao, R.V.; Rai, D.P.; Balic, J. Multi-objective optimization of abrasive waterjet machining process using Jaya algorithm and PROMETHEE Method. J. Intell. Manuf. 2019, 30, 2101-2127. [CrossRef]

46. Nair, A.; Kumanan, S. Optimization of size and form characteristics using multi-objective grey analysis in abrasive water jet drilling of Inconel 617. J. Braz. Soc. Mech. Sci. 2018, 40, 121. [CrossRef]

47. Chakraborty, S.; Mitra, A. Parametric optimization of abrasive water-jet machining processes using grey wolf optimizer. Mater. Manuf. Process. 2018, 33, 1471-1482. [CrossRef]

48. Johari, N.F.; Zain, A.M.; Mustaffa, N.H.; Udin, A. Machining parameters optimization using hybrid firefly algorithm and particle swarm optimization. J. Phys. Conf. Ser. 2017, 892, 012005. [CrossRef]

49. Liu, S.; Zhou, F.; Li, H.; Chen, Y.; Wang, F.; Guo, C. Experimental Investigation of Hard Rock Breaking Using a Conical Pick Assisted by Abrasive Water Jet. Rock Mech. Rock Eng. 2020, 53, 4221-4230. [CrossRef]

50. Madara, S.R.; Selvan, C.P.; Sampath, S.; Pillai, S.R. Impact of process parameters on surface roughness of hastelloy using abrasive waterjet machining technology. Int. J. Recent Technol. Eng. 2019, 7, 419-425.

51. Balamurugan, K.; Uthayakumar, M.; Sankar, S.; Hareesh, U.; Warrier, K. Effect of abrasive waterjet machining on $\mathrm{LaPO}_{4} / \mathrm{Y}_{2} \mathrm{O}_{3}$ ceramic matrix composite. J. Aust. Ceram. Soc. 2018, 54, 205-214. [CrossRef]

52. Krajcarz, D.; Bańkowski, D.; Młynarczyk, P. The Effect of Traverse Speed on Kerf Width in AWJ Cutting of Ceramic Tiles. Procedia Eng. 2017, 192, 469-473. [CrossRef]

53. Lima, C.E.d.A.; Lebrón, R.; de Souza, A.J.; Ferreira, N.F.; Neis, P.D. Study of influence of traverse speed and abrasive mass flowrate in abrasive water jet machining of gemstones. Int. J. Adv. Manuf. Technol. 2016, 83, 77-87. [CrossRef]

54. Kumar, R.S.; Gajendran, S.; Kesavan, R. Evaluation of Optimum Machining Parameters by AWJM for Granite through Multi Response Methods. Mater. Today Proc. 2020, 22, 3056-3066. [CrossRef]

55. Kalusuraman, G.; Kumaran, S.T.; Siva, I.; Kumar, S.A. Cutting performance of luffa cylindrica fiber-reinforced composite by abrasive water jet. J. Test. Eval. 2020, 48, 3417-3428. [CrossRef]

56. Kumar, R.S.; Gajendran, S.; Kesavan, R. Estimation of Optimal Process Parameters for Abrasive Water Jet Machining Of Marble Using Multi Response Techniques. Mater. Today Proc. 2018, 5, 11208-11218. [CrossRef]

57. Yu, Y.; Sun, T.X.; Yuan, Y.M.; Gao, H.; Wang, X.P. Experimental investigation into the effect of abrasive process parameters on the cutting performance for abrasive waterjet technology: A case study. Int. J. Adv. Manuf. Tech. 2020, 107, 2757-2765. [CrossRef]

58. Shibin, R.; Anandakrishnan, V.; Sathish, S.; Sujana, V.M. Investigation on the abrasive water jet machinability of AA2014 using $\mathrm{SiC}$ as abrasive. Mater. Today Proc. 2020, 21, 519-522. [CrossRef]

59. Yogeswaran, R.; Pitchipoo, P. Characterization and machining analysis of AA3003 honeycomb sandwich. Mater. Today Proc. 2020, 28, 4-7. [CrossRef]

60. Shukla, R.; Singh, D. Experimentation investigation of abrasive water jet machining parameters using Taguchi and Evolutionary optimization techniques. Swarm Evol. Comput. 2017, 32, 167-183. [CrossRef]

61. Wang, S.; Zhang, S.; Wu, Y.; Yang, F. Exploring kerf cut by abrasive waterjet. Int. J. Adv. Manuf. Technol. 2017, 93, 2013-2020. [CrossRef]

62. Mohamad, W.; Kasim, M.; Norazlina, M.; Hafiz, M.; Izamshah, R.; Mohamed, S. Effect of standoff distance on the kerf characteristic during abrasive water jet machining. Results Eng. 2020, 6, 100101. [CrossRef]

63. El-Hofy, M.; Helmy, M.; Escobar-Palafox, G.; Kerrigan, K.; Scaife, R.; El-Hofy, H. Abrasive water jet machining of multidirectional CFRP laminates. Procedia CIRP 2018, 68, 535-540. [CrossRef]

64. Perec, A. Experimental research into alternative abrasive material for the abrasive water-jet cutting of titanium. Int. J. Adv. Manuf. Technol. 2018, 97, 1529-1540. [CrossRef] 
65. Li, M.; Huang, M.; Chen, Y.; Kai, W.; Yang, X. Experimental study on hole characteristics and surface integrity following abrasive waterjet drilling of Ti6Al4V/CFRP hybrid stacks. Int. J. Adv. Manuf. Tech. 2019, 104, 4779-4789. [CrossRef]

66. Tiwari, T.; Sourabh, S.; Nag, A.; Dixit, A.R.; Mandal, A.; Das, A.K.; Mandal, N.; Srivastava, A.K. Parametric investigation on abrasive waterjet machining of alumina ceramic using response surface methodology. IOP Conf. Ser. Mater. Sci. Eng. 2018, 377, 012005. [CrossRef]

67. Kaladhar, M.; Subbaiah, K.V.; Rao, C.S. Machining of austenitic stainless steels-a review. Int. J. Mach. Mach. Mater. 2012, 12, 178-192. [CrossRef]

68. Hashish, M. A Modeling Study of Metal Cutting With Abrasive Waterjets. J. Eng. Mater. Technol. 1984, 106, 88-100. [CrossRef]

69. Liu, H.-T.P. Advanced waterjet technology for machining curved and layered structures. Curved Layer. Struct. 2019, 6, 41-56. [CrossRef]

70. Saraçyakupoğlu, T. Abrasive Water Jet (AWJ) Applications in the Aviation Industry. Int. J. Mech. Prod. Eng. Res. Dev. (IJMPERD) 2019, 9, 347-356. [CrossRef]

71. Aurich, J.C.; Kirsch, B.; Setti, D.; Axinte, D.; Beaucamp, A.; Butler-Smith, P.; Yamaguchi, H. Abrasive processes for micro parts and structures. CIRP Ann. 2019, 68, 653-676. [CrossRef]

72. Selvan, M.C.P.; Midhunchakkaravarthy, D.; Senanayake, R.; Pillai, S.R.; Madara, S.R. A mathematical modelling of Abrasive Waterjet Machining on Ti-6Al-4V using Artificial Neural Network. Mater. Today Proc. 2020. [CrossRef]

73. Pahuja, R.; Ramulu, M. Machinability of randomly chopped discontinuous fiber composites: A comparative assessment of conventional and abrasive waterjet. In Proceedings of the 23rd International Conference on Waterjetting, Seattle, WA, USA, 13 November 2016; pp. 127-148.

74. Chen, M.; Zhang, S.; Zeng, J.; Chen, B.; Xue, J.; Ji, L. Correcting shape error on external corners caused by the cut-in/cut-out process in abrasive water jet cutting. Int. J. Adv. Manuf. Technol. 2019, 103, 849-859. [CrossRef]

75. Miao, X.; Qiang, Z.; Wu, M.; Song, L.; Ye, F. Research on quality improvement of the cross section cut by abrasive water jet based on secondary cutting. Int. J. Adv. Manuf. Technol. 2018, 97, 71-80. [CrossRef]

76. Miao, X.; Ye, F.; Wu, M.; Song, L.; Qiang, Z. The method of 3D nozzle tilt cutting of abrasive water jet. Int. J. Adv. Manuf. Technol. 2019, 103, 3109-3114. [CrossRef]

77. Gnanavelbabu, A.; Saravanan, P.; Rajkumar, K.; Karthikeyan, S. Experimental investigations on multiple responses in abrasive waterjet machining of Ti-6Al-4V alloy. Mater. Today Proc. 2018, 5, 13413-13421. [CrossRef]

78. Uthayakumar, M.; Khan, M.A.; Kumaran, S.T.; Slota, A.; Zajac, J. Machinability of nickel-based superalloy by abrasive water jet machining. Mater. Manuf. Process. 2016, 31, 1733-1739. [CrossRef]

79. Khan, M.A.; Gupta, K. Machinability Studies on Abrasive Water Jet Machining of Low Alloy Steel for Different Thickness. IOP Conf. Ser. Mater. Sci. Eng. 2020, 709, 044099. [CrossRef]

80. Yuvaraj, N.; Kumar, M.P. Surface integrity studies on abrasive water jet cutting of AISI D2 steel. Mater. Manuf. Process. 2017, 32, 162-170. [CrossRef]

81. Kechagias, J.; Petropoulos, G.; Vaxevanidis, N. Application of Taguchi design for quality characterization of abrasive water jet machining of TRIP sheet steels. Int. J. Adv. Manuf. Technol. 2012, 62, 635-643. [CrossRef]

82. Naresh Babu, M.; Muthukrishnan, N. Investigation on surface roughness in abrasive water-jet machining by the response surface method. Mater. Manuf. Process. 2014, 29, 1422-1428. [CrossRef]

83. Akkurt, A.; Kulekci, M.K.; Seker, U.; Ercan, F. Effect of feed rate on surface roughness in abrasive waterjet cutting applications. J. Mater. Process. Technol. 2004, 147, 389-396. [CrossRef]

84. Liu, H.; Schubert, E.; McNiel, D.; Soo, K. Applications of abrasive-fluidjets for precision machining of composites. In Proceedings of the International SAMPE Symposium and Exhibition (Proceedings), Seattle, WA, USA, 17-20 May 2010; pp. 17-20.

85. Pashmforoush, F.; Hassanpour Babajan, A.; Beyraghi Baranlou, R. Experimental Study of Geometric Tolerances and Surface Roughness in Abrasive Water Jet Machining Process of Hardox 400 Steel. Modares Mech. Eng. 2020, 20, $953-961$.

86. Perec, A.; Pude, F.; Grigoryev, A.; Kaufeld, M.; Wegener, K. A study of wear on focusing tubes exposed to corundum-based abrasives in the waterjet cutting process. Int. J. Adv. Manuf. Tech. 2019, 104, 2415-2427. [CrossRef]

87. Liu, H.-T. Waterjet technology for machining fine features pertaining to micromachining. J. Manuf. Process 2010, 12, 8-18. [CrossRef]

88. Dong, Y.Z.; Liu, W.W.; Zhang, H.; Zhang, H.C. On-line recycling of abrasives in abrasive water jet cleaning. CIRP Conf. Life Cycle Eng. 2014, 15, 278-282. [CrossRef]

89. Hlavacova, I.; Geryk, V. Abrasives for water-jet cutting of high-strength and thick hard materials. Int. J. Adv. Manuf. Technol. 2017, 90, 1217-1224. [CrossRef]

90. Perec, A.; Pude, F.; Stirnimann, J.; Wegener, K. Feasibility Study on the Use of Fractal Analysis for Evaluating the Surface Quality Generated by Waterjet. Teh. Vjesn. 2015, 22, 879-883. [CrossRef]

91. Melentiev, R.; Fang, F. Recent advances and challenges of abrasive jet machining. CIRP J. Manuf. Sci. Technol. 2018, 22, 1-20. [CrossRef]

92. Hashish, M. Optimization Factors in Abrasive-Waterjet Machining. J. Eng. Ind. 1991, 113, 29-37. [CrossRef]

93. Thamizhvalavan, P.; Arivazhagan, S.; Yuvaraj, N.; Ramesh, B. Machinability study of abrasive aqua jet parameters on hybrid metal matrix composite. Mater. Manuf. Process. 2019, 34, 321-344. [CrossRef]

94. Babu, M.N.; Muthukrishnan, N. Exploration on Kerf-angle and surface roughness in abrasive waterjet machining using response surface method. J. Inst. Eng. 2018, 99, 645-656. [CrossRef]

95. Hashish, M. A Model for Abrasive-Waterjet (AWJ) Machining. J. Eng. Mater. Technol. 1989, 111, 154-162. [CrossRef] 
96. Radovanovic, M. Multi-Objective Optimization of Abrasive Water Jet Cutting Using MOGA. Procedia Manuf. 2020, 47, 781-787. [CrossRef]

97. Nandakumar, N.; Sasikumar, K.; Sambathkumar, M.; Saravanan, N. Investigations on AWJ cutting process of hybrid aluminium 7075 metal matrix composites using nozzle oscillation technique. Mater. Today Proc. 2020, 33, 2798-2802. [CrossRef]

98. Sasikumar, K.; Arulshri, K.; Ponappa, K.; Uthayakumar, M. A study on kerf characteristics of hybrid aluminium 7075 metal matrix composites machined using abrasive water jet machining technology. J. Eng. Manuf. 2018, 232, 690-704. [CrossRef]

99. Ishfaq, K.; Ahmad Mufti, N.; Ahmed, N.; Pervaiz, S. Abrasive waterjet cutting of cladded material: Kerf taper and MRR analysis. Mater. Manuf. Process. 2019, 34, 544-553. [CrossRef]

100. Karmiris-Obratański, P.; Karkalos, N.E.; Kudelski, R.; Papazoglou, E.L.; Markopoulos, A.P. On the Effect of Multiple Passes on Kerf Characteristics and Efficiency of Abrasive Waterjet Cutting. Metals 2021, 11, 74. [CrossRef]

101. Yuvaraj, N.; Kumar, M.P. Cutting of aluminium alloy with abrasive water jet and cryogenic assisted abrasive water jet: A comparative study of the surface integrity approach. Wear 2016, 362, 18-32. [CrossRef]

102. Mardi, K.B.; Dixit, A.; Mallick, A. Studies on non-traditional machining of metal matrix composites. Mater. Today Proc. 2017, 4, 8226-8239. [CrossRef]

103. Srinivas, S.; Babu, N.R. Penetration Ability of Abrasive Waterjets in Cutting of Aluminum-Silicon Carbide Particulate Metal Matrix Composites. Mach. Sci. Technol. 2012, 16, 337-354. [CrossRef]

104. Gostimirovic, M.; Pucovsky, V.; Sekulic, M.; Rodic, D.; Pejic, V. Evolutionary optimization of jet lag in the abrasive water jet machining. Int. J. Adv. Manuf. Technol. 2019, 101, 3131-3141. [CrossRef]

105. Hanif, M.I.; Aamir, M.; Ahmed, N.; Maqsood, S.; Muhammad, R.; Akhtar, R.; Hussain, I. Optimization of facing process by indigenously developed force dynamometer. Int. J. Adv. Manuf. Technol. 2019, 100, 1893-1905. [CrossRef]

106. Kumar, P.; Kant, R. Development of a predictive model for kerf taper angle in AWJM of Kevlar epoxy composite. Mater. Today Proc. 2020, 28, 1164-1169. [CrossRef]

107. Otto, K.N.; Antonsson, E.K. Extensions to the Taguchi Method of Product Design. J. Mech. Des. 1993, 115, 5-13. [CrossRef]

108. Aamir, M.; Tu, S.S.; Tolouei-Rad, M.; Giasin, K.; Vafadar, A. Optimization and Modeling of Process Parameters in Multi-Hole Simultaneous Drilling Using Taguchi Method and Fuzzy Logic Approach. Materials 2020, 13, 680. [CrossRef] [PubMed]

109. Rao, R.V.; Rai, D.P.; Balic, J. Optimization of Abrasive Waterjet Machining Process using Multi-objective Jaya Algorithm. Mater. Today Proc. 2018, 5, 4930-4938. [CrossRef]

110. Nair, A.; Kumanan, S. Multi-performance optimization of abrasive water jet machining of Inconel 617 using WPCA. Mater. Manuf. Process. 2017, 32, 693-699. [CrossRef]

111. Opricovic, S.; Tzeng, G.H. Extended VIKOR method in comparison with outranking methods. Eur. J. Oper. Res. 2007, 178, 514-529. [CrossRef]

112. Rao, R. Jaya: A simple and new optimization algorithm for solving constrained and unconstrained optimization problems. Int. J. Ind. Eng. Comp. 2016, 7, 19-34.

113. Fan, Z.; Liu, E.; Xu, B. Weighted principal component analysis. In International Conference on Artificial Intelligence and Computational Intelligence; Springer: Berlin/Heidelberg, Germany, 2011; pp. 569-574. 